\title{
Türk Medyasında Yaban Hayatı Kaçakçılığı
}

\author{
Wildlife Smuggling in the Turkish Media
}

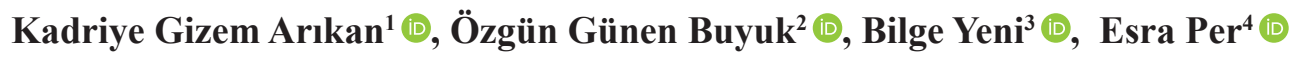

${ }^{1}$ (Doktora Öğrencisi), Gazi Üniversitesi, Fen Fakültesi, Biyoloji Bölümü, Ankara, Türkiye ${ }^{2}$ (Yüksek Lisans Öğrencisi), Gazi Üniversitesi, Fen Fakültesi, Biyoloji Bölümü, Ankara, Türkiye ${ }^{3}$ (Arş. Gör.), Nevşehir Hacı Bektaş Veli

Üniversitesi, Fen-Edebiyat Fakültesi, Biyoloji Bölümü, Nevșehir,Türkiye

${ }^{4}$ (Doç. Dr.), Gazi Üniversitesi, Fen Fakültesi, Biyoloji Bölümü, Ankara, Türkiye

ORCID: K.G.A.0000-0002-2461-9620; Ö.G.B. 0000-0001-7063-1447;

B.Y. 0000-0002-4543-4844;

E.P. 0000-0002-7764-1215

Corresponding author:

Esra PER

Gazi Üniversitesi, Fen Fakültesi, Biyoloji

Bölümü, Ankara, Türkiye

E-mail address: esraper@gazi.edu.tr

Submitted: 04.08.2021

Revision Requested: 28.10 .2021

Last Revision Received: 27.11.2021

Accepted: 30.11.2021

Citation: Arikan, K. G., Buyuk, O. G., Yeni, B. ve Per, E. (2021). Türk medyasında yaban hayatı kaçakçılığı. Acta Infologica, 5(2), 299-317. publication. https://doi.org/10.26650/acin.978812
ÖZ

Türkiye biyoçeşitlilik açısından küçük bir kıta özelliği göstermektedir. Ülkede yerli türlerin yasal ticareti (özel izinler dışında) mümkün olmamakla birlikte, bazı yabancı ve evcil türlerin yasal ticareti yapılmaktadır. Bu nedenle zaman zaman kaçakçılık vakaları görülebilmektedir. Daha önce ülke genelinde medyada biyokaçakçılık ile ilgili bir değerlendirme yapılmamıştır. Bu çalışmada kaçakçılık haberleri Google arama motorunda farklı anahtar kelimeler kullanılarak araştırılmıştır. Bu haberler tarih, materyal türü (fosil, soğan, tohum, deri, tırnak, kürk, boynuz, diş, yumurta, zehir, birey), formu (canlı, ölü), takım, familya, cins, tür, coğrafi bölge ve il verileri kullanılarak analiz edilmiştir. Araştırma sonucunda 1999 - 2020 yılları arasında Türkiye'de bu konuda toplam 517 haber tespit edilmiştir. Yapılan haberlerin \% 45'i biyokaçakçılık (yerli tür), \% 44'ü egzotik tür, \% 7'si çiftlik hayvanı ve \%2'si evcil tür kaçakçılı̆̆ üzerinedir. Son on yılda özellikle canlı birey yerine bitki soğanı, diş, deri, post, kabuk ve kürk gibi vücut parçalarının kaçakçılığında dikkat çekici bir artış olmuştur. Kaçakçılık haberlerinin \%49’u Marmara Bölgesi’nde yapılmıştır. Bu oranda hava limanı üzerinden yapılan kaçakçılık ile İstanbul ve karayolu kaçakçılığı ile Edirne ön plana çıkmaktadır. Bu araştırma ile bitki, mantar ve hayvansal organizmaların kaçakçılığı hakkında Türk Medyası'nda yer bulmuş olan haberlerin tarihçesi ve genel durumu ortaya çıkarılmıştır. Bu haberlerin \% 37'si 2020 yılında yapılmıştır. Bu oranda, Covid 19 pandemisi nedeniyle uluslararası yaban hayatı ticaretinin askıya alınmış olmasının etkili olduğu düşünülmektedir.

Anahtar kelimeler: Farkındalık, Biyoçeşitlilik, Covid 19, Kitle İletişim Araçları, Yaban Hayatı Ticareti

\section{ABSTRACT}

In terms of biodiversity, Turkey has the qualities of a small continent. Although it is not possible to legally trade the native species in the country (unless special permits are obtained), certain exotic and domestic species can be legally traded. For this reason, there are occasional cases of smuggling. There has been no assessment of bio-smuggling in the media across the country. In this study, news stories concerning smuggling were searched using different keywords in the Google search engine. These news items were analyzed in terms of the date, material type (fossil, bulb, seed, skin, nail, fur, horn, tooth, egg, poison, and individual), form (alive, dead), order, family, genus, species, geographical region, and province data. Of the news items analyzed, $45 \%$ were about bio-smuggling (native species), $44 \%$ exotic species, $7 \%$ farm animals and $2 \%$ pet smuggling. In the last ten years, there has been a remarkable increase in the trade of plant bulbs, teeth, skin, hides, shell and fur as opposed to live specimens. The Marmara Region was the source of $49 \%$ of the news items on smuggling. Within this region, Istanbul stands out in terms of the trade carried out through the airport, and Edirne with its land route trade. The history and current situation of news in Turkish media regarding the smuggling of wildlife species have been discovered as a result of this study. Of the news items analyzed, $37 \%$ were reported in 2020 . The suspension of international wildlife trafficking due to the Covid 19 pandemic is thought to have an effect on this rate.

Keywords: Awareness, Biodiversity, Covid 19, Mass Media, Wildlife Trade 


\section{GíRİ̧̧}

Rachel Carson, Sessiz Bahar adlı eserinde "doğadaki canlı cansız her öge; durgun bir suya atılan taşın oluşturduğu halkalar gibi sorunlardan etkilenir" demiştir (Carson, 1962). Dolayısıyla insan kaynaklı her faaliyet sadece insanların yaşadıkları yerdeki canlıları değil dünya genelindeki biyoçeşitliliği de etkilemektedir. Çünkü biyoçeşitlilik birbirine bağımlı üç farklı katmandan (genetik çeşitlilik, tür çeşitliliği ve ekosistem çeşitliliği) oluşur (Reece vd., 2020). Bu katmanlarda oluşacak en ufak bir değişim, özellikle ekolojik toleransı düşük türler için yok oluş anlamına gelir (Mayr, 2008) ve bu değişim hem türlerin doğal yayılış gösterdiği alanlarda hem de türlerin başka yerlere taşınması sürecinde gerçekleşebilir.

Biyoçeşitlilik ekolojik açıdan önemli olduğu gibi ekonomi, etik ve estetik açıdan da önemlidir (Aruoba, 2005). Zengin biyoçeşitliliğe sahip bölgelerdeki ekosistemler fakir ekosistemlere göre daha dengelidir. Bu bölgelerde doğal dengenin tahrip edilmesi zordur ve kendini yenileme özelliğini daha kolay gösterir (Yıldız vd., 2005). Doğal kaynakların oluşturduğu canl1cansız biyoçeşitlilik değerleri, endüstri, tarım, turizm ve sağlık sektörleri açısından kalkınma potansiyelinin de bir göstergesidir. Gelecekte yenilenemeyen enerji kaynaklarının tükenecek olması, insanlığın geleceği açısından biyoçeşitliliğin önemini göstermektedir (Kence, 1991). Biyolojik çeşitliliğin korunması, biyolojik kaynakların sürdürülebilir kullanımı ve genetik kaynakların kullanımından kaynaklanan faydaların adil paylaşımı amacıyla Biyolojik Çeşitlilik Sözleşmesi; Hayvan ve Bitki Türlerinin Canlı-Cansız Örneklerinin Uluslararası Ticaretini Düzenleyen (nesli tükenme tehlikesi ile karşı karşıya kalan bitki ve hayvan türlerinin neslini devam ettirmek amacıyla) Sözleşme olan CITES, Gıda ve Tarım için Bitki Genetik Kaynakları Uluslararası Anlaşması (FAO), Avrupa’nın Yaban Hayatı ve Yaşama Ortamlarını Koruma Sözlesmesi olan BERN Sözleşmesi önemlidir (Çakmak, 2008; Keçeli vd., 2013).

Biyoçeşitliliğin korunması için Dünya Doğayı ve Doğal Kaynakları Koruma Birliği (IUCN)'nin öncülüğünde, Birleşmiş Milletler tarafından da kabul edilen CITES Sözleşmesi 3 Mart 1973 tarihinde 88 ülke tarafından imzalanarak yürürlüğe girmiştir (CITES, 2020). Türkiye bu sözleşmeye 1996 yılında imza atmıştır. Ulusal mevzuatı sözleşmeye uygun hale getirmek için ilgili kurumlar 2001 yılına kadar ortak çalışmış, 2004 yılında bu sözleşme kapsamında uygulanacak hükümlerle ilgili bir yönetmelik yayınlanmıştır (Tarım ve Orman Bakanlığı, 2020). Bu sözleşme ile yabani türlerin, bulundukları ülke sınırlarından ilgili kamu kurumlarının izni olmadan çıkarılmasının önüne geçilmesi, yani biyokaçakçılığın engellenmesi amaçlanmıştır (Keçeli vd., 2013). Biyokaçakçılığa karşı uluslararası hukuki dayanaklara göre, ülkelerin kendi sınırları içerisinde bulunan canlı veya cansız (madenler, su, tarihi eserler, vb.) doğal kaynaklarla ilgili yasal düzenlemeler yapma hakkı vardır (Keçeli vd., 2013).

Flora ve fauna açısından Türkiye yüksek endemizm oranıyla zengin bir biyolojik çeşitliliğe sahiptir (Dayığlu vd., 2019). Biyolojik çeşitlilik alanında mevcut olan veri eksikliğine rağmen, yaklaşık 4.000'i endemik olan 19.000 omurgasız türüne, 70'ini balık türlerinin oluşturduğu 100'den fazla endemik taksona sahip 1500 omurgalı türüne ve ayrıca 3.000'den fazlası endemik olan yaklaşık 11.700 bitki türüne ev sahipliği yapmaktadır. Tüm Avrupa kıtasında 12.500 bitki türü varken, Anadolu’nun tek başına bu sayıya yakın bir değere sahip olması Türkiye’nin biyolojik zenginliğinin önemli bir göstergesidir. Bunun yanı sıra süzülen kuşlar açısından önemli olan iki büyük kuş göç rotasının Türkiye üzerinden geçmesi söz konusu bu türlerin göçü, üremesi, konaklaması ve beslenmesi açısından önem arz etmektedir (Tarım ve Orman Bakanlığı, 2019; Güner vd., 2012). Türkiye'de 171 memeli (Tramem, 2020), 485 kuş (Trakuş, 2020), 120 sürüngen (Budak \& Göçmen, 2008), 30 iki yaşamlı (Budak \& Göçmen, 2008), 716 balık ve yaklaşık 30.000 böcek türü (UBSEP, 2007) doğal yayılış göstermektedir.

Türkiye'nin biyoçeşitlilik açısından zengin olmasının başlıca sebepleri; Akdeniz, Avrupa-Sibirya ve İran-Turan fitocoğrafik bölgelerine sahip olması ve bu üç bölgenin kesişim noktasında Anadolu Çaprazı’nın olması, üç kıta arasındaki konumu, yıl boyunca dört farklı mevsimin görülmesi ve topografya farklılığıdır (Akman vd., 2005).

Ulusal düzenlemeler gereğince Türkiye'deki yabani türlerin doğadan toplanması, birey ya da türe ait parçaların yurt dışına çıkarılması kurallara bağlı izne tabiidir. Belgesiz olarak hiçbir tür veya parçası yurt dışına taşınamaz. Bu bağlamda kontrol belgeleri, sağlık sertifikası, CITES belgesi ve materyal taşıma anlaşması belgelerine sahip olmak gerekir (Keçeli vd., 2013). $\mathrm{Bu}$ durum bilimsel araştırma amacıyla yurt dışına gönderilmek istenen örnekleri de kapsamaktadır. Bu konudaki yasal düzenlemeler Resmî Gazete’de (RG) yayınlanmaktadır.

"Doğadan yabani canlıların ve onlara ait parçaların yetkili makamların izni olmadan toplanması ve yurt dışına çıkartılması 
“biyokaçakçılık” olarak adlandırılmaktadır.”(Keçeli vd., 2013). Türkiye’de biyokaçakçılığın önlenmesi amacıyla yapılan yasal düzenlemeler, Av ve Yaban Hayvanlarının ve Yaşam Alanlarının Korunması, Zararlılarıyla Mücadele Usul ve Esasları Hakkında Yönetmelik (24 Aralık 2005 tarih ve 25976 sayılı RG), Bitki Genetik Kaynaklarının Toplanması, Muhafazası ve Kullanılması Hakkında Yönetmelik (5 Ağustos 1992 tarih ve 21316 sayılı RG), Nesli Tehlike Altında Olan Yabani Hayvan ve Bitki Türlerinin Uluslararası Ticaretine İlişkin Sözleşmenin Uygulanmasına Yönelik Yönetmelik (27.12.2001 tarih ve 24623 sayılı RG), Doğal Çiçek Soğanlarının Üretimi, Doğadan Toplanması ve İhracatına İlişkin Yönetmelik (19 Temmuz 2012 Tarih ve 28358 Sayı RG), Evcil Hayvan Genetik Kaynaklarının Korunması ve Sürdürülebilir Kullanımı Hakkında Yönetmelik (22 Aralık 2011 tarih ve 28150 sayılı RG), Su Ürünleri Yönetmeliği (10 Mart 1995 tarih ve 22223 sayılı RG), Türkiye'de İlmi Araştırma, İnceleme Yapmak ve Film Çekmek İsteyen Yabancılar veya Yabancılar Adına Müracaat Edenler ile Yabancı Basın-Yayın Mensuplarının Tabi Olacakları Esaslar (Bakanlar Kurulu Karar Sayısı: 88/12839 Kabul Tarihi : 4/4/1988) olarak sıralanabilir (Keçeli vd., 2013).

Türkiye'de biyokaçakçıllı̆̆n tespitinde uygulanacak işlemler, 2872 sayılı Çevre Kanunu 20/k bendine göre yapılmakta ve para cezası uygulanmaktadır (Keçeli vd., 2013). Yurt dışından belgesiz/kayıt dışı olarak yurda getirilme durumu ise yasadışı yollarla elde edilen canlı av ve yaban hayvanları olarak değerlendirildiğinden, Kara Avcıllı̆̆ Kanunu'na muhalefet ve Ticaret Esaslarına uymamak olarak tarif edilir ve işlemler 4915 Sayılı Kara Avcılı̆̆ Kanuna göre devam ettirilerek para cezası uygulanmaktadır (Resmî Gazete, 2005). Günümüzde dünyada yabani tür kaçakçılığı, uyuşturucu ve silah kaçakçılığından sonra gelmekte olan 10 milyar dolar değerindeki en büyük üçüncü yasa dışı ticari faaliyettir. Özellikle Latin Amerika ülkeleri sahip oldukları zengin canlı çeşitliliği ile dünyada en çok yaban hayvanı kaçakçılığına maruz kalan ülkelerdir (Bergman, 2009). Biyolojik çeşitlilik açısından zengin olan Türkiye de tıpkı Latin Amerika ülkeleri gibi biyokaçakçılık için ilgi odağı haline gelmektedir.

Türkiye'de, bilimsel çalışmalar, koleksiyonlar ve ticari amaçlar için biyokaçakçılık yapıldığı (Budak \& Göçmen, 2008) ve yabancı araştırmacıların Türkiye'nin doğal türlerini kaçırdıklarına dair bir çok çalışma bilinmektedir (Özbek, 2016). Kaçakçılığa maruz kalan canlı grupları; endemik ve/veya sınırlı alanlarda yayılış gösteren türler, kültür bitkilerinin yabani akrabaları, sağlık sektöründe kullanılan türler, çiftlik hayvanları ve bu hayvanların yabani akrabaları ile yerel ırkları olarak sıralanabilir. Biyokaçakçılık sonucunda ortaya çıkan ekolojik bozulmalar ise; birey sayısında azalma, popülasyon sayı ve dağılımında azalma ve ekosistem bileşenlerinin dengesinin bozulması ile ekosistem tahribatı olarak özetlenebilir (Kurt vd., 2019).

Türkiye; tıbbi, kozmetik vb. alanlarda yürütülen çalışmalardan dolayı biyokaçakçılık vakalarına maruz kalmaktadır (Yorulmaz, 2014). Ülkemizde biyoçeşitlilik ve biyokaçakçılık konusunda bilinç oluşturmak amacıyla Tarım ve Orman Bakanlığı bünyesinde görev yapan Doğa Koruma ve Milli Parklar Genel Müdürlüğü (DKMP) tarafından 2013 yllında "Biyokaçakçılıkla Mücadele Rehberi” yayınlanmıştır (Güler \& Mutlu, 2018). Türkiye'de DKMP'ye bağlı bölge müdürlüklerindeki şube müdürlüklerinde ekipler kurulmuş olsa da bu ekiplere emniyet güçleri de yardımcı olmaktadır. Bu ekiplerin dışında doğrudan biyokaçakçılıkla ilgilenen devlet idarelerine bağlı özel bir ekip bulunmamaktadır.

Yasadışı hayvan ticaretine karşı Dünya Gümrük Örgütü (WCO) büyük önem arz etmektedir (Tempier, 2014). Biyokaçakçılık konusunda uluslararası düzeyde yayınlanmış en önemli sözleşme CITES'dir. CITES uygulama yönetmeliğine göre DKMP yönetim mercii konumundadır (Tarım ve Orman Bakanlı̆̆ı, 2020). Bilimsel mercii ise TÜBİTAK’tır (Resmî Gazete, 2001). Tarım ve Orman Bakanlığı'nın biyokaçakçılık üzerine yaptığı çalışmalar ile vatandaşların farkındalığının artışına paralel olarak bu konuda ihbarlar artmaya başlamıştır. Vatandaşlar biyokaçakçılık vakaları ile karşılaştığında Emniyet Genel Müdürlüğü (EGM) ve Ticaret Bakanlığı’na online ihbar formu ile veya ALO 136 ihbar hattını arayarak durumu bildirebilmektedir (Keçeli vd., 2013). Biyokaçakçılık konusunda yapılan farkındalık çalışmaları araştırmacılar ve karar verici kurumların daha fazla vatandaşa ulaşmasına katkı sağlamaktadır.

Türkiye'de biyolojik çeşitliliğin genel durumu, riskler, olası tehditler ve tedbirlere dair araştırmalar bulunmaktadır (Karagöz vd., 2010). Devletin karar verici kurumları bu konuyla ilgili uzman ekipleri oluşturmaya çalışmakta, eksik kalınan noktalarda Sivil Toplum Kuruluşları (STK)'nda görev yapan uzmanlardan ve ilgili üniversite bölümlerindeki akademisyen kadrolarından katkı istemektedir (Özbek, 2016). İnsanın yeryüzünü tarım, sanayi ve teknolojik gelişmelerle değiştirmesi, nüfus artışı sebebiyle insan-doğa etkileşimi ve biyoçeşitliliği korumaya yönelik sorunlar son yıllarda dikkat çekici biçimde artış 
göstermektedir (Koç \& Soykan, 2020). Türkiye’nin zengin biyoçeşitliliği farklı etmenlerden olumsuz etkilenmektedir. Bu olumsuz etmenlerden biri de İstilacı Yabancı Türlerin (IYT) Türkiye’ye çeşitli şekillerde girmiş olmasıdır (Özdemir \& Ceylan, 2007). Evcil hayvan yetiştiriciliği ve bazı peyzaj çalışmaları için egzotik türlere olan ilgi de yabancı türlerin Türkiye'ye girişine sebep olmakta ve bu türlerin bir kısmının istilacı özellik göstermesiyle de dolaylı yoldan biyoçeşitliliğe zarar verilebilmektedir. İstilacı yabancı tür girişlerinin bir kısmı yasal ticari yollardan, bir kısmı kaçakçılık ve diğer bir kısmı da insanın doğaya olan müdahaleleri ile gerçekleşmektedir.

Türkiye'de çevre ve doğa eğitiminde medyanın önemli bir yeri vardır. Bu kapsamda 2006 yılında çıkarılmış olan Çevre Kanunu'nda medyaya önemli görevler yüklenmiştir. Türkiye Radyo Televizyon Kurumu (TRT) ile Özel Televizyon (TV) kanalları ve Özel Radyo kanallarının yayın akışlarında çevre ve doğa üzerine eğitici yayınlar olması zorunludur. Çevre ve doğa üzerine olan yayınların \%20'sinin vatandaşların en çok TV izlediği ve radyo dinlediği saat aralıklarında olması gereklidir (Gürcüoğlu, 2013). Türkiye'de ilk olarak Türkiye Bilimsel ve Teknolojik Araştırma Kurumu (TÜBİTAK)'nun popüler bilim yayıncılığı yapması ve sonrasında gazetelerin yayın politikalarına göre bilim haberleri yapmaları söz konusu olmuştur. Ancak Türkiye'de yayınlanan gazeteler arasında okuyucuya ulaşmada önde olan ilk dört gazete bilim haberleri konusunda zayıf kalmıştır. Bu da gazetelerin bilim haberlerine önem vermediklerini ve bilimin gazeteler için haber değeri taşımadığını göstermektedir (Öztekin ve Şahin, 2020). Türkiye'de gazete okuma oranı nüfusun yaklaşık \%30'luk bir kısmına denk gelmektedir (Güçlü \& Kökmen, 2014). Türkiye'de halkın biyoçeşitlilik konusunda farkındalığının artmasında yazılı ve görsel basının önemli bir misyonu vardır.

Yaban hayatı kaçakçılık vakaları Tarım ve Orman Bakanlığı, İçişleri Bakanlığı (Kaçakçılık Suçlarıyla Mücadele Şube Müdürlüğü) ve Adalet Bakanlığı tarafından basın kuruluşları ile paylaşılmaktadır, ancak ülke genelinde medyada yaban hayatı kaçakçılığı ile ilgili bir değerlendirme yapılmamıştır. Bu araştırmanın amacı, Türkiye'de yaban hayatı kaçakçılığı ile ilgili internet temelli haberler üzerine çok boyutlu bibliyometrik bir değerlendirme yaparak, hem yerli hem de yabancı türler açısından Türkiye'deki kaçakçılığın boyutlarını ortaya çıkarmaktır.

\section{YÖNTEM}

Google arama motoru, internet temelli ve halkın erişimine açık olan bir araştırma aracıdır. Google'da bulunan yaban hayatı kaçakçıllğı temelli haberler bilgisayar destekli tarama yöntemi ile farklı anahtar kelimeler kullanılarak araştırılmıştır. Farklı medya kuruluşlarının web sitelerinde kaçakçılık haberlerinin arşivlenmiş olması bu değerlendirmeye olanak sağlamıştır.

Google arama motorunda sorgulamalar 22.10.2020-15.12.2020 tarihleri arasında şu anahtar kelimelere göre yapılmıştır; arı kaçakçılık, balık kaçakçılık, bitki kaçakçılık, biyokaçakçılık bitki, biyokaçakçılık hayvan, böcek kaçakçılık, büyükbaş hayvan kaçakçılık, CITES kaçakçılık, egzotik bitki kaçakçılık, egzotik hayvan kaçakçılık, gümrük bitki, gümrük hayvan, haşhaş kaçakçılık, hayvan boynuzu kaçakçılık, hayvan kaçakçılık, kaçakçılık mücadele şube müdürlüğü bitki, kaçakçılık mücadele şube müdürlüğü hayvan, kedi kaçakçılık, kelebek kaçakçılık, kenevir kaçakçılık, köpek kaçakçılık, kurbağa kaçakçılık, kuş kaçakçılık, kuş yumurtası kaçakçılık, küçükbaş hayvan kaçakçılık, mantar kaçakçılık, sahlep kaçakçılık, tohum kaçakçılık, yasa dışı bitki ticaret, yasa dışı hayvan ticareti ve yılan kaçakçılık.

Google arama motoru aracıllğı ile tespit edilmiş olan bütün haberlerin bibliyografik künyeleri referans gösterilebilecek şekilde düzenlenmiştir. Elde edilen veriler Microsoft Excel programında bir veri tabanı hâline getirilmiştir. Tespit edilen haberlerin; tarih, materyal türü (boynuz, deri, diş, fosil, kabuk, kürk, post, pul, soğan, tahnit, tırnak, tohum, tüy, yumurta, zehir), formu (canlı, ölü), takım, familya, cins, tür, coğrafi bölge ve il verileri üzerine bir değerlendirme ve analiz yapılmıştır. $\mathrm{Bu}$ araştırmada biyokaçakçılık alanında yerli türlerin yasa dışı olarak taşınmasına dair vakalar dışında yabancı/egzotik, evcil türler ve çiftlik hayvanlarının yasa dışı ticaretine dair vakalar da değerlendirmeye alınmıştır.

Bu bibliyometrik veri tabanının kapsamını ve sınırlarını 22.10.2020-15.12.2020 tarihleri arasında Google arama motorunda yapılan sorgulamalarda kayıtlı olan yayınlar belirlemişsir. Sorgulamalarda tespit edilmiş olan bütün haberler pdf biçiminde arşivlenmiştir. Tekrar eden haberlerde eleme yapılmıştır. Elde edilen verilerden özet tablo ve frekans analizleri yapılmıştır.

Anahtar kelimeleri değerlendirmek için internet üzerinden Wordart kelime bulutu analizi kullanılmıştır (Wordart, 2021). 


\section{BULGULAR}

Türkiye'de 1999-2020 yılları arasında bitki hayvan ve mantar kaçakçılığı üzerine toplam 517 haber tespit edilmiştir. Bu haberlerin \%24'ü bitkiler, \%75'i hayvanlar ve \%1'i mantarlar üzerinedir. Genel olarak bu konuda yapılmış haberlerin \%67'si görsel belgeler ile desteklenmişken, \%33’ü görsel belgeler ile desteklenmemiştir. Görsel belgeler ile desteklenmiş olan haberlerin \%31'i bitkiler, \%68'i hayvanlar ve \%1'i mantarlar üzerine olup, görsel belgeler ile desteklenmeyen haberlerin \%9'u bitkiler, \%90'ı hayvanlar ve \%1'i mantarlar üzerinedir. Genel olarak bu konuda yapılmış haberlerin \%35'i yerel ölçekli, \%65’i ulusal ölçekli haberlerdir. Yerel haber kaynaklarından temin edilmiş olan vakaların \%44'ü bitkiler, \%55'i hayvanlar ve \%2'si mantarlar üzerinedir. Ulusal haber kaynaklarından temin edilmiş olan vakaların \%17'si bitkiler, \%82'si hayvanlar ve \%1'i mantarlar üzerinedir (Tablo 1).

Tablo 1

Kaçakçılık haberlerinin organizma kökeni, görsel belgelerle desteklenmesi ve haber ölçeğine göre \%’lik değişimi

\begin{tabular}{|c|c|c|c|c|c|c|c|c|c|c|}
\hline & $\begin{array}{c}\text { Canlının } \\
\text { kökeni }\end{array}$ & $\%$ & $\begin{array}{l}\text { Haberlerde görsel } \\
\text { var }\end{array}$ & $\%$ & $\begin{array}{c}\text { Haberlerde görsel } \\
\text { yok }\end{array}$ & $\%$ & $\begin{array}{r}\text { Yerel } \\
\text { haber }\end{array}$ & $\%$ & $\begin{array}{l}\text { Ulusal } \\
\text { haber }\end{array}$ & $\%$ \\
\hline Bitki & 123 & 24 & 108 & 31 & 15 & 9 & 58 & 44 & 65 & 17 \\
\hline Hayvan & 389 & 75 & 233 & 68 & 156 & 90 & 73 & 55 & 316 & 82 \\
\hline Mantar & 5 & 1 & 3 & 1 & 2 & 1 & 2 & 2 & 3 & 1 \\
\hline Toplam & 517 & 100 & 344 & 100 & 173 & 100 & 133 & 100 & 384 & 100 \\
\hline
\end{tabular}

Yapılan haberlerin dönemsel olarak yıllara göre değişimi Şekil 1'de gösterilmiştir. Bu haberlerin 2010'a kadar çok sınırlı sayıda olduğu 2015 yılında bir ivme kazanmaya başladığı, en büyük artışın ise 2020 yılında gerçekleştiği görülmektedir. 21 y1llık süreçte kaçakçılık vakaları üzerine yıllık ortalama 25 haber tespit edilmiştir. Bu haberlerin \%37'sinin (192 haber) 2020 yılında yapılmış olması dikkat çekicidir.

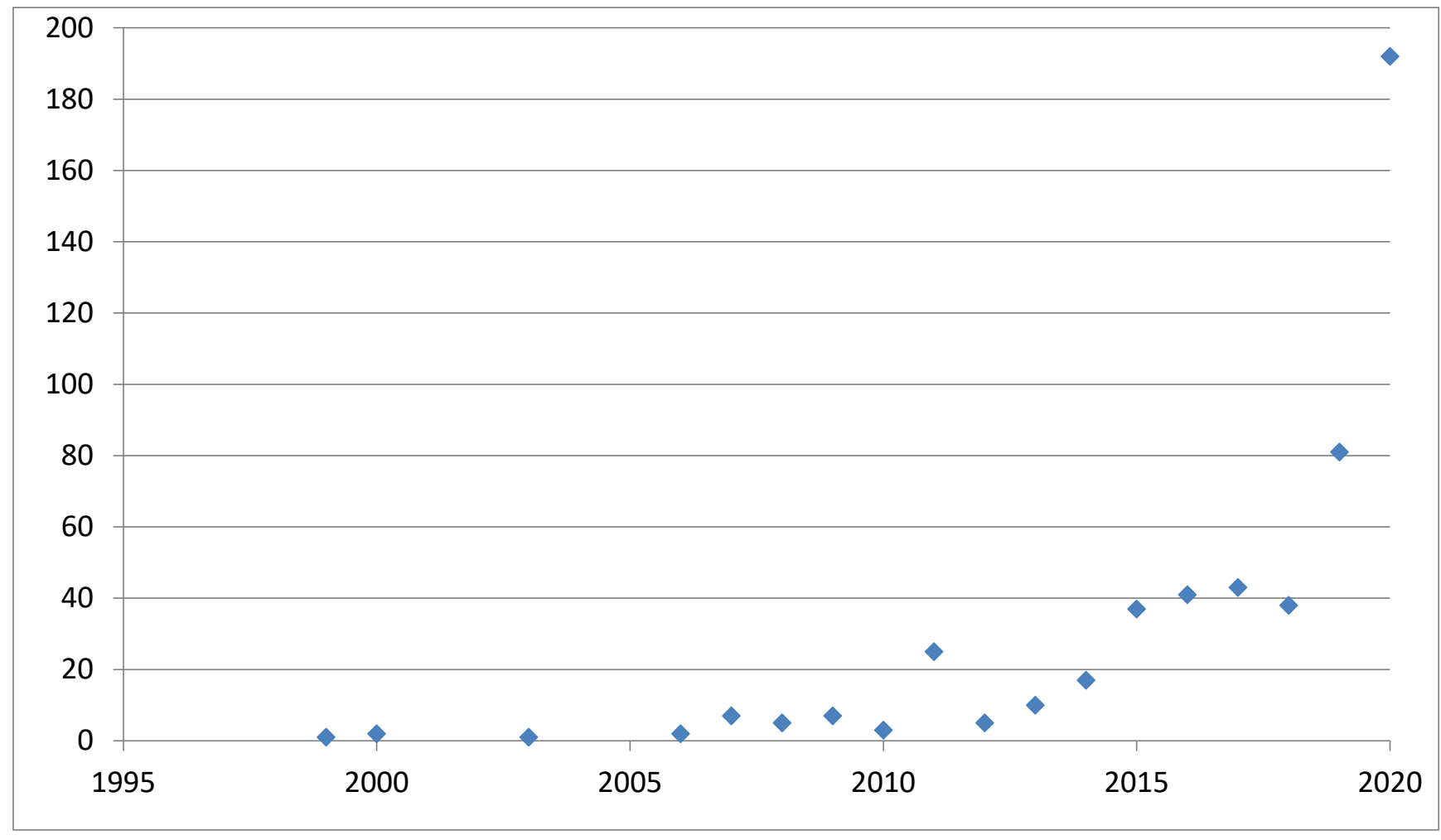

Şekil 1. Kaçakçılık haberlerinin yıllara göre dağılımı

Bu haberler yıllara göre karşılaştırmalı olarak incelendiğinde hayvan kaçakçılığı haberlerinin başlangıcı 1999 yılına, bitki haberlerinin başlangıcı ise 2008 yılına dayanmaktadır. Ayrıca bitki temelli haber sayısının hayvan temelli haberlere göre daha düşük sayıda olduğu tespit edilmiştir. Hayvan kaçakçılığı haberleri 2005-2010 yılları arasında dalgalı bir dağılım 
gösterirken hem bitki hem de hayvan kaçakçılığı 2010 yılından itibaren haberlerde daha çok yer bulmaya başlamıştır. Her iki grup için de en fazla haber 2020 yılında yapılmıştır (Şekil 2). Mantar kaçakçılığına dair haberler 2018-2020 yılları arasında yapılmıştır.

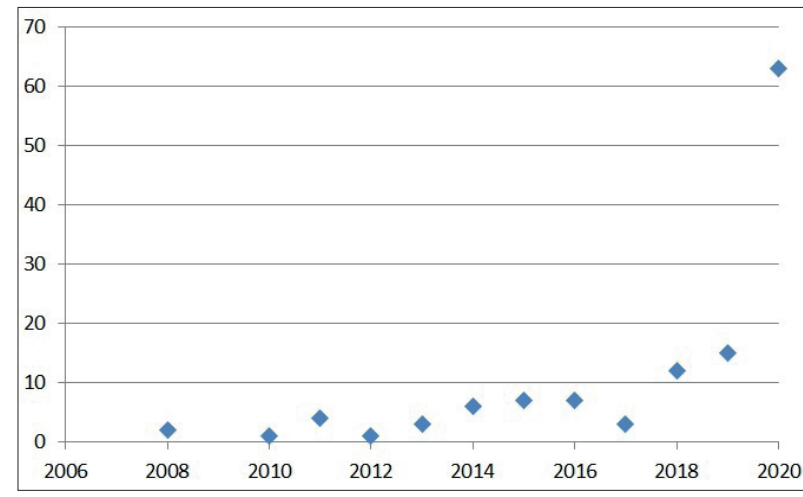

A

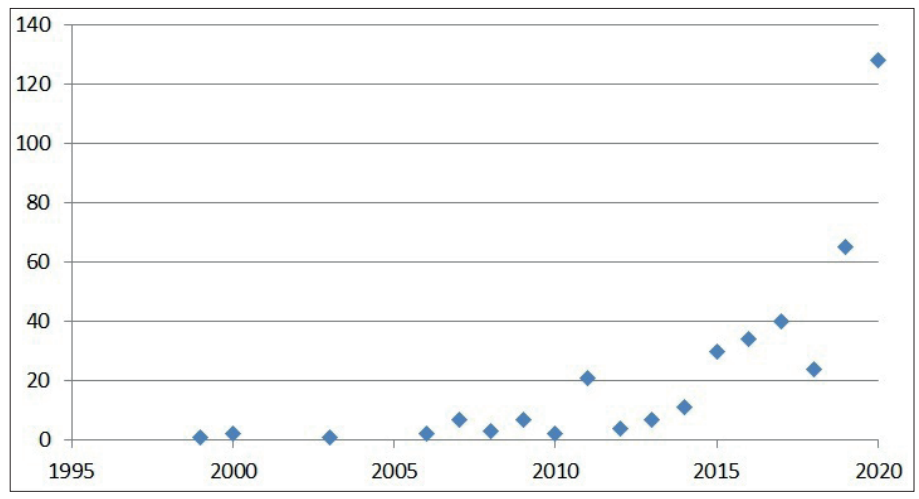

B

Şekil 2. Yıllara göre bitki (A) ve hayvan (B) temelli kaçakçılık haberlerinin değişimi

Kaçakçılık haberlerinin coğrafi bölgelere göre dağılımı Şekil 3’te verilmiştir. Bu haberlerin coğrafi bölgelere göre yüzdelik oranı karşılaştırıldığında ilk sırayı \%49’luk oran ile Marmara Bölgesi almaktadır. Diğger bölgeler ise sırasıyla; Akdeniz Bölgesi (\%13), Doğu Anadolu Bölgesi (\%10), Güneydoğu Anadolu Bölgesi (\%9), Karadeniz Bölgesi (\%7), Ege Bölgesi (\%6) ve İç Anadolu Bölgesi (\%6) şeklindedir.

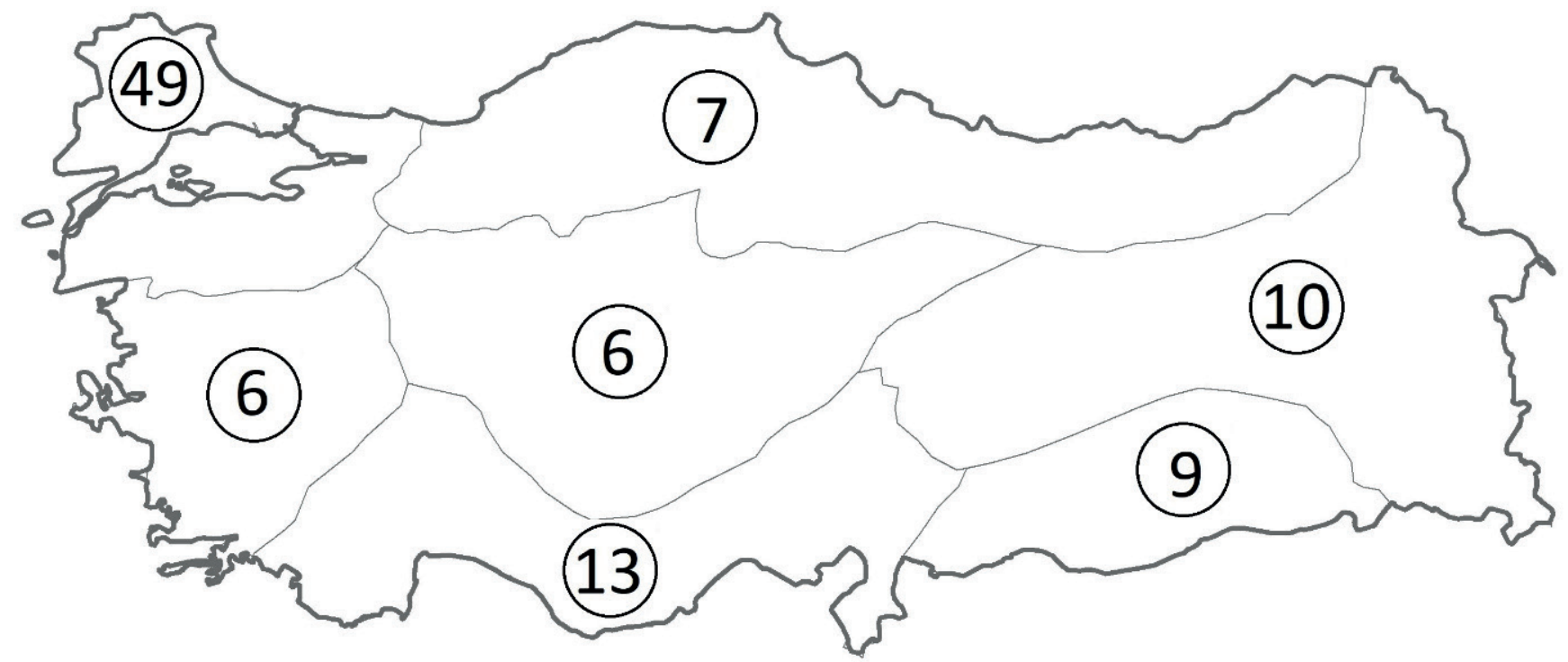

Şekil 3. Coğrafi bölgelere göre kaçakçılık haberlerinin yüzdelik dağılımı

Türkiye'de toplam 61 ilde yaban hayatı kaçakçılığı vakaları üzerine haber yapılmıştır. En fazla vaka İstanbul (\%34), Edirne $(\% 7,7)$ ve Diyarbakır $(\% 4,4)$ illerinde tespit edilmiştir. Takip eden iller ise, Antalya, Adana, Ankara, Hatay, Kırklareli, Kütahya ve Elâzığ'dır (Tablo 2). 
Tablo 2

Kaçakçılık haberlerinin illere göre dağılımı

\begin{tabular}{|c|c|c|c|c|c|c|c|}
\hline Sira & İl & Sıklık (f) & \% Dağılımı & Sira & İl & Sıklık (f) & \% Dağılımı \\
\hline 1 & Adana & 14 & 2,7 & 32 & İstanbul & 176 & 34,0 \\
\hline 2 & Adiyaman & 2 & 0,4 & 33 & İzmir & 4 & 0,8 \\
\hline 3 & A ğr1 & 4 & 0,8 & 34 & Kahramanmaraş & 4 & 0,8 \\
\hline 4 & Aksaray & 2 & 0,4 & 35 & Kars & 6 & 1,2 \\
\hline 5 & Amasya & 3 & 0,6 & 36 & Kirklareli & 13 & 2,5 \\
\hline 6 & Ankara & 14 & 2,7 & 37 & Kilis & 6 & 1,2 \\
\hline 7 & Antalya & 16 & 3,1 & 38 & Kocaeli & 9 & 1,7 \\
\hline 8 & Ardahan & 6 & 1,2 & 39 & Konya & 3 & 0,6 \\
\hline 9 & Artvin & 8 & 1,5 & 40 & Kütahya & 10 & 1,9 \\
\hline 10 & Aydın & 5 & 1,0 & 41 & Malatya & 8 & 1,5 \\
\hline 11 & Balıkesir & 2 & 0,4 & 42 & Manisa & 3 & 0,6 \\
\hline 12 & Bartın & 1 & 0,2 & 43 & Mardin & 2 & 0,4 \\
\hline 13 & Batman & 1 & 0,2 & 44 & Mersin & 7 & 1,4 \\
\hline 14 & Bilecik & 3 & 0,6 & 45 & Muğla & 4 & 0,8 \\
\hline 15 & Bingöl & 3 & 0,6 & 46 & Nevşehir & 6 & 1,2 \\
\hline 16 & Bolu & 1 & 0,2 & 47 & Niğde & 2 & 0,4 \\
\hline 17 & Burdur & 3 & 0,6 & 48 & Osmaniye & 1 & 0,2 \\
\hline 18 & Bursa & 4 & 0,8 & 49 & Rize & 2 & 0,4 \\
\hline 19 & Çorum & 3 & 0,6 & 50 & Sakarya & 5 & 1,0 \\
\hline 20 & Denizli & 2 & 0,4 & 51 & Samsun & 1 & 0,2 \\
\hline 21 & Diyarbakır & 23 & 4,4 & 52 & Siirt & 3 & 0,6 \\
\hline 22 & Edirne & 40 & 7,7 & 53 & Sinop & 1 & 0,2 \\
\hline 23 & Elâzı ̆̆ & 10 & 1,9 & 54 & Sivas & 1 & 0,2 \\
\hline 24 & Erzincan & 1 & 0,2 & 55 & Şanlıurfa & 2 & 0,4 \\
\hline 25 & Erzurum & 4 & 0,8 & 56 & Şırnak & 2 & 0,4 \\
\hline 26 & Eskişehir & 2 & 0,4 & 57 & Tekirdağ & 9 & 1,7 \\
\hline 27 & Gaziantep & 5 & 1,0 & 58 & Tokat & 5 & 1,0 \\
\hline 28 & Gümüşhane & 9 & 1,7 & 59 & Tunceli & 1 & 0,2 \\
\hline 29 & Hakkâri & 5 & 1,0 & 60 & Van & 4 & 0,8 \\
\hline 30 & Hatay & 14 & 2,7 & 61 & Zonguldak & 6 & 1,2 \\
\hline 31 & Iğdır & 1 & 0,2 & - & Toplam & 211 & 100 \\
\hline
\end{tabular}

Türkiye'de kaçakçılığa en çok maruz kalan hayvan sınıfı; kuşlar (\%40) olup, bunu sırasıyla, memeliler (\%24), böcekler (\%15), sürüngenler (\%9), iki yaşamlılar (\%6) ve örümceğimsiler (\%6) takip etmektedir (Şekil 4).

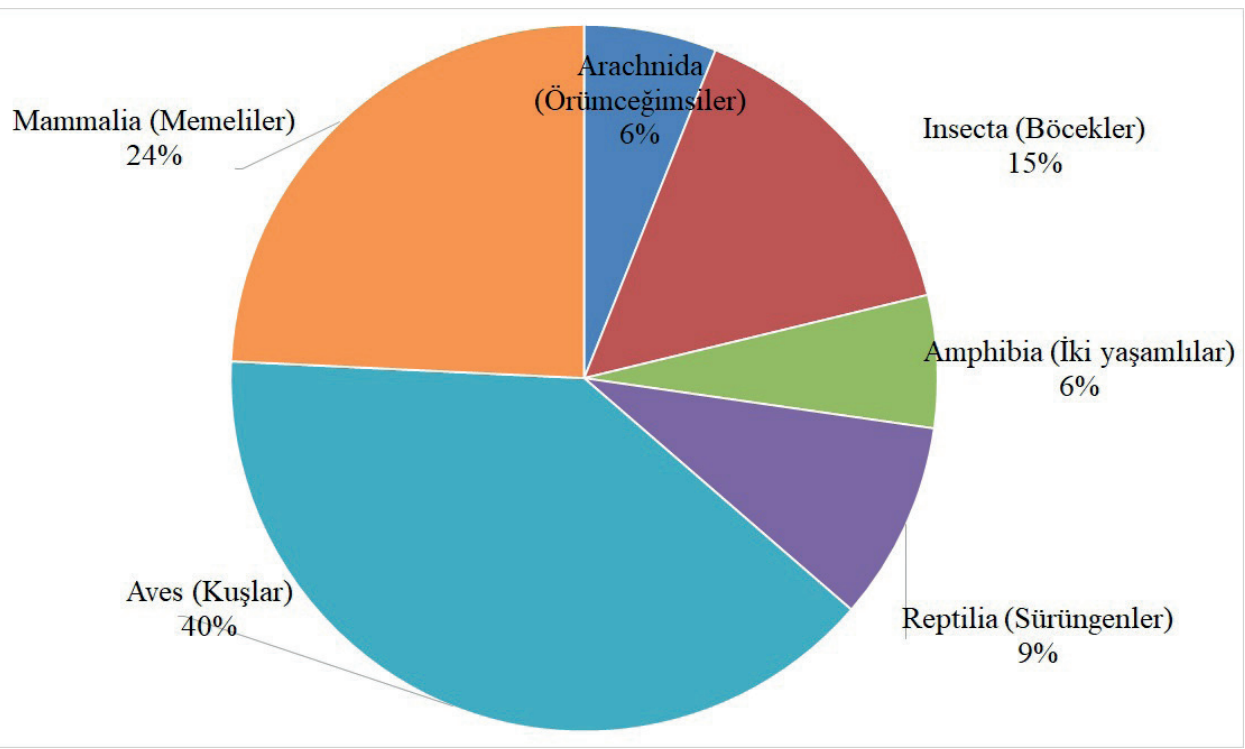

Şekil 4. Türkiye'de kaçakçılık vakalarının hayvan sınıflarına göre dağılımı 
Haberlere konu olan hayvanların dâhil oldukları şubeler ve oranları; Arthropoda (Eklembacaklılar) \%18 ve Chordata (Omurgalılar) \%82'dir. Bu şube ve sınıflara ait 33 takım tespit edilebilmiştir. Kaçakçılık haberlerlerinde en çok taksonla temsil edilen takımlar sırasıyla, Squamata (Pullular) \%22,9; Artiodactyla (Çift toynaklılar) \%10,3; Psittaciformes (Papağanlar) \%9; Carnivora (Etçiller) \%8,2; Passeriformes (Ötücüler) \%6,9; Anura (Kuyruksuz kurbağalar) \%4,4; Lepidoptera (Pul kanatlılar) \%3,6 ve Proboscidea (Hortumlular) \%3,1'dir (Tablo 3).

Tablo 3

Kaçakçılık haberlerine konu olan hayvanların takım temelli \%’lik dağılımları

\begin{tabular}{|c|c|c|c|c|c|}
\hline Sira & Şube & Sinıf & Takım & Sıklık (f) & \% Dağılımı \\
\hline 1 & Arthropoda (Eklembacaklılar) & Arachnida (Örümceğimsiler) & Araneae (Örümcekler) & 8 & 2,1 \\
\hline 2 & Arthropoda (Eklembacaklılar) & Arachnida (Örümceğimsiler) & Scorpiones (Akrepler) & 2 & 0,5 \\
\hline 3 & Arthropoda (Eklembacaklılar) & Insecta (Böcekler) & Coleoptera (Kın kanatlılar) & 4 & 1,0 \\
\hline 4 & Arthropoda (Eklembacaklılar) & Insecta (Böcekler) & Diptera (Sinekler) & 2 & 0,5 \\
\hline 5 & Arthropoda (Eklembacaklilar) & Insecta (Böcekler) & Hemiptera (Yarım kanatlılar) & 3 & 0,8 \\
\hline 6 & Arthropoda (Eklembacaklılar) & Insecta (Böcekler) & Hymenoptera (Zar kanatlılar) & 2 & 0,5 \\
\hline 7 & Arthropoda (Eklembacaklılar) & Insecta (Böcekler) & Lepidoptera (Pul kanatlılar) & 14 & 3,6 \\
\hline 8 & Chordata (Omurgalılar) & Amphibia (İki yaşamlılar) & Anura (Kuyruksuz kurbağalar) & 17 & 4,4 \\
\hline 9 & Chordata (Omurgalılar) & Amphibia (İki yaşamlılar) & Caudata (Semenderler) & 1 & 0,3 \\
\hline 10 & Chordata (Omurgalılar) & Aves (Kuşlar) & Accipitriformes (Gündüz yırtıcıları) & 7 & 1,8 \\
\hline 11 & Chordata (Omurgalılar) & Aves (Kuşlar) & Anseriformes (Kazsılar) & 9 & 2,3 \\
\hline 12 & Chordata (Omurgalılar) & Aves (Kuşlar) & Columbiformes (Güvercinler) & 5 & 1,3 \\
\hline 13 & Chordata (Omurgalılar) & Aves (Kuşlar) & Falconiformes (Doğangiller) & 4 & 1,0 \\
\hline 14 & Chordata (Omurgalılar) & Aves (Kuşlar) & Galliformes (Tavuksular) & 7 & 1,8 \\
\hline 15 & Chordata (Omurgalılar) & Aves (Kuşlar) & Passeriformes (Ötücüler) & 27 & 6,9 \\
\hline 16 & Chordata (Omurgalılar) & Aves (Kuşlar) & Phoenicopteriformes (Flamingolar) & 2 & 0,5 \\
\hline 17 & Chordata (Omurgalılar) & Aves (Kuşlar) & Piciformes (Ağaçkakansılar) & 1 & 0,3 \\
\hline 18 & Chordata (Omurgalılar) & Aves (Kuşlar) & Psittaciformes (Papağanlar) & 35 & 9,0 \\
\hline 19 & Chordata (Omurgalılar) & Aves (Kuşlar) & Pteroclidiformes (Bağırtlakgiller) & 2 & 0,5 \\
\hline 20 & Chordata (Omurgalilar) & Aves (Kuşlar) & Rheiformes (Amerikan devekuşları) & 1 & 0,3 \\
\hline 21 & Chordata (Omurgalılar) & Aves (Kuşlar) & Strigiformes (Baykuşgiller) & 3 & 0,8 \\
\hline 22 & Chordata (Omurgalılar) & Aves (Kuşlar) & Struthioniformes (Devekuşları) & 2 & 0,5 \\
\hline 23 & Chordata (Omurgalılar) & Mammalia (Memeliler) & Artiodactyla (Çift toknaklılar) & 40 & 10,3 \\
\hline 24 & Chordata (Omurgalılar) & Mammalia (Memeliler) & Carnivora (Etçiller) & 32 & 8,2 \\
\hline 25 & Chordata (Omurgalılar) & Mammalia (Memeliler) & Lagomorpha (Tavşanımsılar) & 2 & 0,5 \\
\hline 26 & Chordata (Omurgalılar) & Mammalia (Memeliler) & Perissodactyla (Tek toynaklılar) & 7 & 1,8 \\
\hline 27 & Chordata (Omurgalılar) & Mammalia (Memeliler) & Pholidota (Pangolinler) & 3 & 0,8 \\
\hline 28 & Chordata (Omurgalılar) & Mammalia (Memeliler) & Primates (Primatlar) & 8 & 2,1 \\
\hline 29 & Chordata (Omurgalılar) & Mammalia (Memeliler) & Proboscidea (Hortumlular) & 12 & 3,1 \\
\hline 30 & Chordata (Omurgalılar) & Mammalia (Memeliler) & Rodentia (Kemirgenler) & 5 & 1,3 \\
\hline 31 & Chordata (Omurgalılar) & Reptilia (Sürüngenler) & Crocodilia (Timsahlar) & 5 & 1,3 \\
\hline 32 & Chordata (Omurgalılar) & Reptilia (Sürüngenler) & Squamata (Pullular) & 89 & 22,9 \\
\hline 33 & Chordata (Omurgalilar) & Reptilia (Sürüngenler) & Testudines (Kaplumbağalar) & 3 & 0,8 \\
\hline 34 & - & - & Bilinmiyor & 25 & 6,4 \\
\hline 35 & - & - & Toplam & 364 & 100 \\
\hline
\end{tabular}

Kaçakçılık haberlerine konu olan bitkilerin \%50'si Monocotyledoneae (Tek çenekliler), \%50'si Dicotyledoneae (Çift çenekli bitkiler)'dir. Bu bitkilerin dâhil oldukları takımlardan altısı bilinmektedir. Kaçaklık haberlerlerinde en çok taksonla temsil edilen bitki takımları sırasıyla, Rosales (Güller) \%46,8; Ranunculales (Düğünçiçekleri) \%26,6; Asparagales (Kuşkonmazlar) \%16,.9'dur (Tablo 4). Bu araştırmada ekonomik açıdan değerli olan Pezizales takımında yer alan, Tuberaceae familyasından olan trüf mantarlarının biyokaçakçılığa maruz kaldığı tespit edilmiştir. 
Tablo 4

Kaçakçılık haberlerine konu olan bitkilerin takım temelli \%'lik dağılımları

\begin{tabular}{|c|c|c|c|c|}
\hline Sira & Sinıf & Takım & Sıklık (f) & Yüzde (\%) Dağılımı \\
\hline 1 & Monocotyledoneae (Tek çenekliler) & Asparagales & 21 & 16,9 \\
\hline 2 & Monocotyledoneae (Tek çenekliler) & Liliales & 1 & 0,8 \\
\hline 3 & Monocotyledoneae (Tek çenekliler) & Ranunculales & 33 & 26,6 \\
\hline 4 & Dicotyledoneae (Çift çenekli bitkiler) & Rosales & 58 & 46,8 \\
\hline 5 & Dicotyledoneae (Çift çenekli bitkiler) & Caryophyllales & 1 & 0,8 \\
\hline 6 & Dicotyledoneae (Çift çenekli bitkiler) & Poales & 1 & 0,8 \\
\hline- & - & Bilinmiyor & 9 & 7,3 \\
\hline - & - & Toplam & 124 & 100 \\
\hline
\end{tabular}

Kaçakçılık vakalarında tespit edilen bitkilerin cinsleri Şekil 5’te gösterilmiştir. Vakalar bitki cinsleri açısından gruplandırıldığında, \%47 Cannabis (Kenevir), \%26 Papaver (Haşhaş) ve \%15 Ophrys (Orkide) cinsleri bitki kaçakçılı̆̆ haberlerinde ön plana çıkmıştır (Şekil 5). Ophrys cinsi yabani bitki türlerini temsil etmektedir. Cannabis ve Papaver cinslerinin kaçak olarak ekimi yapılmaktadır. Uyuşturucu-halüsinojen madde içerikli bitkilerin kaçakçılığı 2010-2020 yılları arasında bir artış göstermiştir.

Bu araştırmada biyokaçakçılığa maruz kaldığg tespit edilen ve Türkiye'de doğal yayılış gösteren bitki türleri; Safran (Crocus sativus), Sarıdudak (Fritillaria michailovskyi), Likya Kaş orkidesi (Ophrys lycia) ve yabani Gernik buğdayı (Tritucum dicoccoides)'dir.

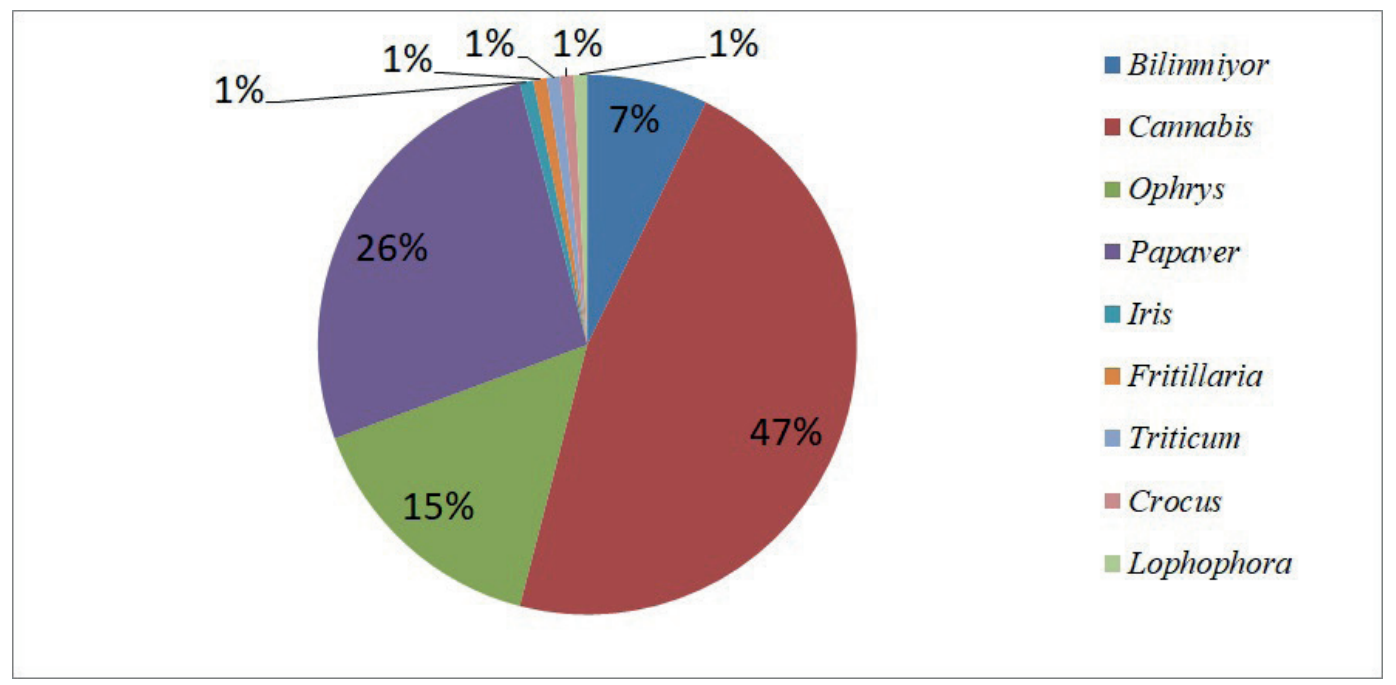

Şekil 5. Tespit edilen bitki cinslerinin \% dağılımı

Vakalar hayvan cinsleri açısından gruplandırıldığında 517 vakanın 251 (\%65)'inin cins adı tespit edilmiş olmakla birlikte veri eksikliğinden dolayı 138 vakanın (\%35) cins bilgisi tespit edilememiştir. Tespit edilebilmiş olan 43 cins Tablo 5’te sınıflandırılmıştır. Bu değerlendirmede en yüksek oranlara sahip cinsler ve temsil ettikleri canlılar; Bos (büyükbaş çiftlik hayvanı) (\%5), Carduelis (saka) (\%6), Nymphicus (sultan papağan1) (\%1), Pogona (sakallı ejder) (\%2), Psittacula (papağan) $(\% 4)$, Pyton (piton yılanı) (\%1) ve Ovis (evcil koyun) \%3)'dir. Bu cinslerden Carduelis yerli türleri kapsamaktadır. Diğer cinsler egzotik ve çiftlik hayvanlarını temsil etmektedir.

Medyada yayınlanan haberlerde biyokaçakçılığa maruz kaldığı tespit edilen ve Türkiye'de doğal yayılış göstermekte olan hayvan türleri; akyanaklı kaz (Branta leucopsis), angıt (Tadorna ferruginea), atmaca (Accipiter nisus), bağırtlak (Pterocles orientalis), bıldırcın (Coturnix coturnix), boz kaz (Anser anser), delice doğan (Falco subbuteo), flamingo (Phoenicopterus roseus), geyik böceği (Lucanus cervus), gökdoğan (Falco peregrinus), kafkas burunlu engereği (Vipera transcaucasiana), kınalı keklik (Alectoris chukar), kızıl şahin (Buteo rufinus), kurt (Canis lupus), saka (Carduelis carduelis) şahin (Buteo buteo) ve yeşilbaş (Anas platyrhynchos)'tır. 
Egzotik tür olarak; Afrika boğa kurbağası (Pyxicephalus adspersus), Afrika devekuşu (Struthio camelus), beyazgerdanlı tukan (Ramphastos tucanus), boğa yılanı (Boa constrictor), büyük rea (Rhea americana), çiğdeci (Acridotheres tristis), çöl varanı (Varanus griseus), gri papağan (Psittacus erithacus), hint bülbülü (Taeniopygia guttata), iguana (Iguana iguana), Java ispinozu (Lonchura oryzivora), Kalifornia kral yılanı (Lampropeltis californiae), kara kuğu (Cygnus atratus), kızıl palmiye böceği (Rhynchophorus ferrugineus), lama (Lama glama), mandarin ördeği (Aix galericulata), mavi dilli kertenkele (Tiliqua scincoides scincoides), mavi sar1 ara (Ara ararauna), Meksika siyah kral y1lanı (Lampropeltis getula nigrita), mısır yılanı (Pantherophis guttatus), muhabbet kuşu (Melopsittacus undulates), Nil varanı (Varanus niloticus), puma (Puma concolor), rakun (Procyon lotor), serval (Leptailurus serval), sultan papağanı (Nymphicus hollandicus), tavuskuşu (Pavo cristatus) ve yeşil papağan (Psittacula krameri) tespit edilmiştir.

Tablo 5

Kaçakçılık haberlerine konu olan hayvanların cins temelli sistematik olarak\%'lik dağılımları

\begin{tabular}{|c|c|c|c|c|c|c|c|}
\hline Sira & Cins & Sıklık (f) & \% Dağılımı & Sira & Cins & Sıklık (f) & \% Dağılımı \\
\hline 1 & Acanthopelma & 4 & 1 & 24 & Leptailurus & 2 & 1 \\
\hline 2 & Accipiter & 3 & 1 & 25 & Lithobates & 2 & 1 \\
\hline 3 & Acrantophis & 1 & 1 & 26 & Macaca & 4 & 1 \\
\hline 4 & Acridotheres & 1 & 1 & 27 & Mammuthus & 2 & 1 \\
\hline 5 & Alectoris & 3 & 1 & 28 & Manis & 2 & 1 \\
\hline 6 & Anser & 3 & 1 & 29 & Melopsittacus & 4 & 1 \\
\hline 7 & Antaresia & 7 & 2 & 30 & Nymphicus & 5 & 1 \\
\hline 8 & Ara & 6 & 2 & 31 & Odobenus & 2 & 1 \\
\hline 9 & Bison & 2 & 1 & 32 & Ovis & 11 & 3 \\
\hline 10 & Bos & 21 & 5 & 33 & Panthera & 2 & 1 \\
\hline 11 & Bubo & 2 & 1 & 34 & Pantherophis & 2 & 1 \\
\hline 12 & Buteo & 4 & 1 & 35 & Pavo & 2 & 1 \\
\hline 13 & Canis & 8 & 2 & 36 & Phoenicopterus & 2 & 1 \\
\hline 14 & Carduelis & 24 & 6 & 37 & Pogona & 6 & 2 \\
\hline 15 & Castor & 2 & 1 & 38 & Psittacula & 17 & 4 \\
\hline 16 & Columba & 4 & 1 & 39 & Pterocles & 2 & 1 \\
\hline 17 & Crocodylus & 2 & 1 & 40 & Python & 15 & 4 \\
\hline 18 & Cygnus & 3 & 1 & 41 & Struthio & 2 & 1 \\
\hline 19 & Falco & 4 & 1 & 42 & Tiliqua & 2 & 1 \\
\hline 20 & Felis & 8 & 2 & 43 & Varanus & 6 & 2 \\
\hline 21 & Gekko & 3 & 1 & 44 & Diğer Cins & 40 & 10 \\
\hline 22 & Iguana & 2 & 1 & 45 & Bilinmiyor & 138 & 35 \\
\hline 23 & Lampropeltis & 2 & 1 & 46 & Toplam & 389 & 100 \\
\hline
\end{tabular}

Haberlere konu olan organizmaların (bitki, hayvan ve mantar) canlı veya ölü olma durumlarına göre dağılımı Şekil 6'da verilmiştir. Yakalanan organizmaların \%52'si canlı, \%18'i ölü olarak ele geçirilmiştir. Yakalanan organizmaların \%30'unun ise durumu bilinmemektedir. 


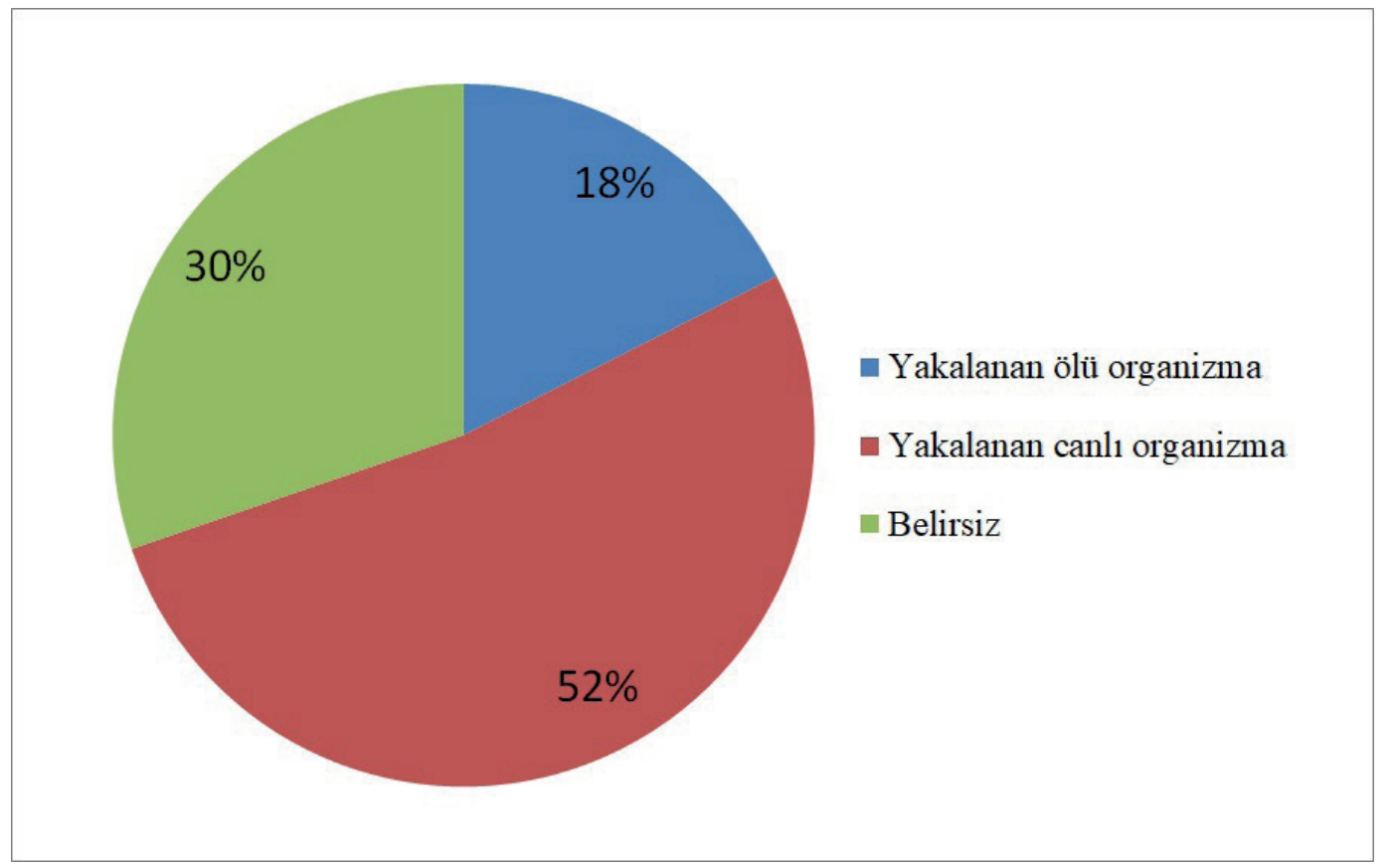

Şekil 6. Kaçakçılık haberlerine konu olan organizmaların canlı/ölü olma durumuna göre \% dağılımları

Kaçakçılığa konu olan canlı grupları her zaman bir bütün halinde olmayıp boynuz, yumurta, post, soğan, tohum gibi kısımlar da kaçakçılığa maruz kalabilmektedir. Kaçakçılığı yapılan organizmaların vücut parçalarına ait dağılım Şekil 7'de verilmiştir. Bitkisel kökenli parçalarda; soğanlar \%25'lik oran ile birinci sırayı alırken, hayvansal kökenli parçalarda; \%24 oranıyla deri/ post/kürk/kabuk kısımları ikinci sırada ve \%22’lik oran ile diş örnekleri üçüncü sırada yer almaktadır. Bunları boynuz (\%13), fosil (\%8) ve tohum (\%4) parçaları takip etmektedir. Kaçakçılığa konu olan diğer materyaller ise pul, tahnit, tırnak, tüy ve yumurtadır. Özellikle 2010-2020 yılları arasında organizmaların vücut parçalarına ait kaçakçılık vakalarında artış olmuştur.

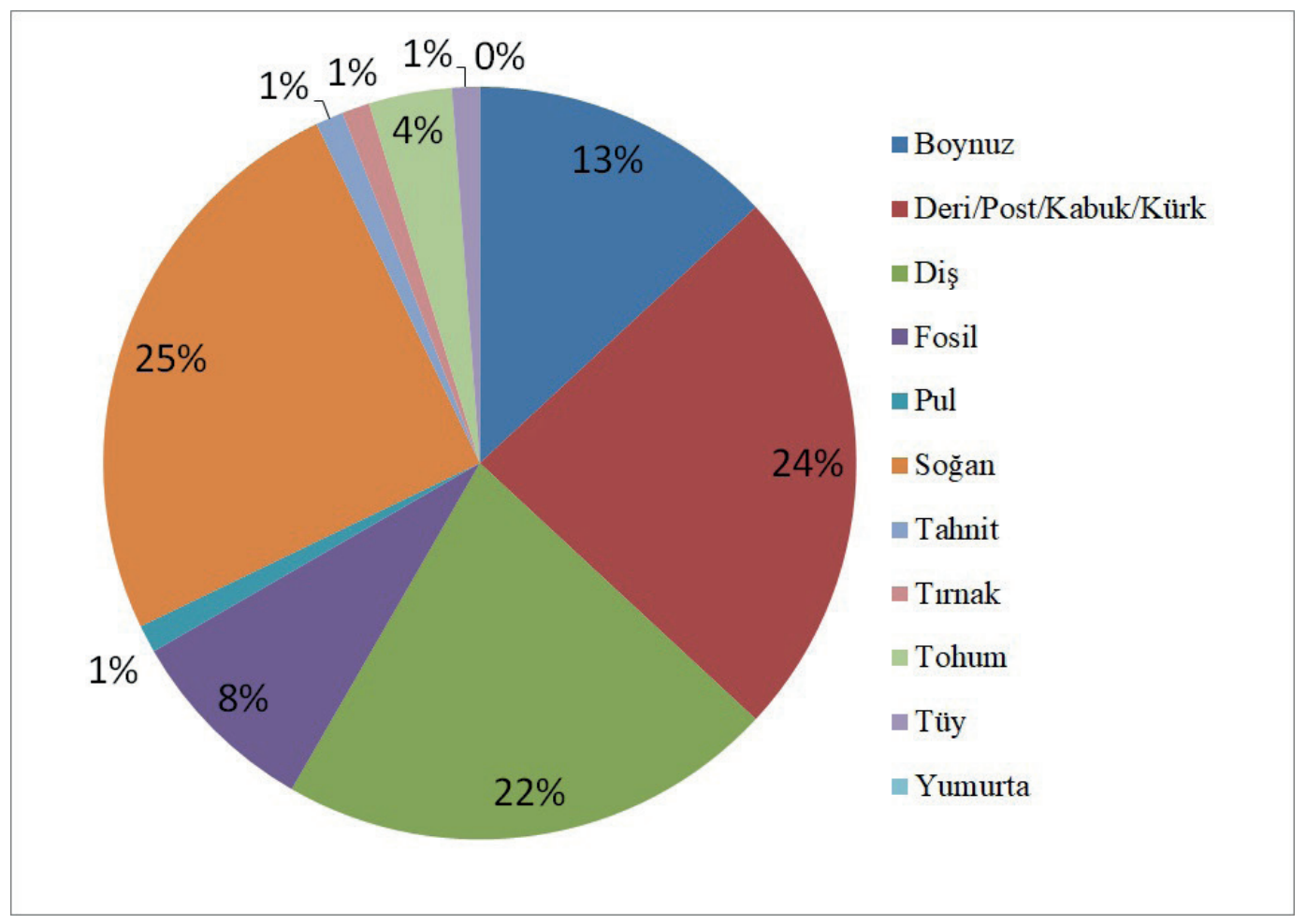

Şekil 7. Kaçakçılığı yapılan organizma parçalarının \% dağılımları 
Araştırmada kullanılmış olan anahtar kelimeler üzerine yapılmış olan bulut analizinde 517 vaka arasında en çok kullanılmış olan anahtar kelimeler sırasıyla; Hin keneviri kaçakçılık, kuş kaçakçılık, egzotik hayvan kaçakçılık, hayvan boynuzu kaçakçılık, kaçakçılık mücadele şube müdürlüğü, haşhaş kaçakçılık ve CITES kaçakçılık’tır (Şekil 8). Organizmaların vücut parçalarına ait kaçakçılık vakalarında \%22'lik bir orana sahip olan hayvan dişlerine (Şekil 7) dikkat çekmek için kelime bulutu simgesi olarak fil seçilmiştir.

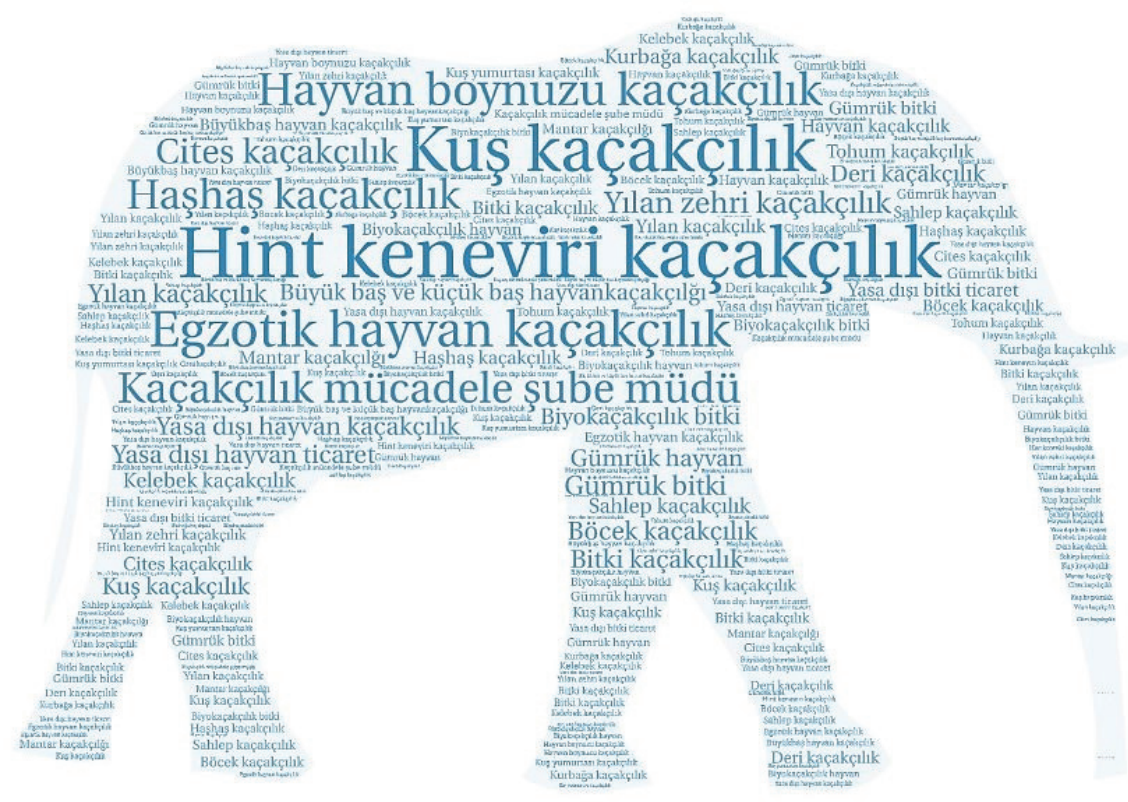

Şekil 8. Araştırmada kullanılan anahtar kelimelerin kelime bulutu analizi

Farklı statülerden canlı gruplarının maruz kaldığı kaçakçılığı gösteren oranlar karşılaştırıldığında tespit edilen en yüksek kaçakçılık oranları sırasıyla biyokaçakçılık (yerli tür) \%45, egzotik/yabancı tür kaçakçılığı \%44, çiftlik hayvanı kaçakçılığı \%7 ve evcil hayvanı kaçakçılığ1 \%2’dir (Şekil 9).

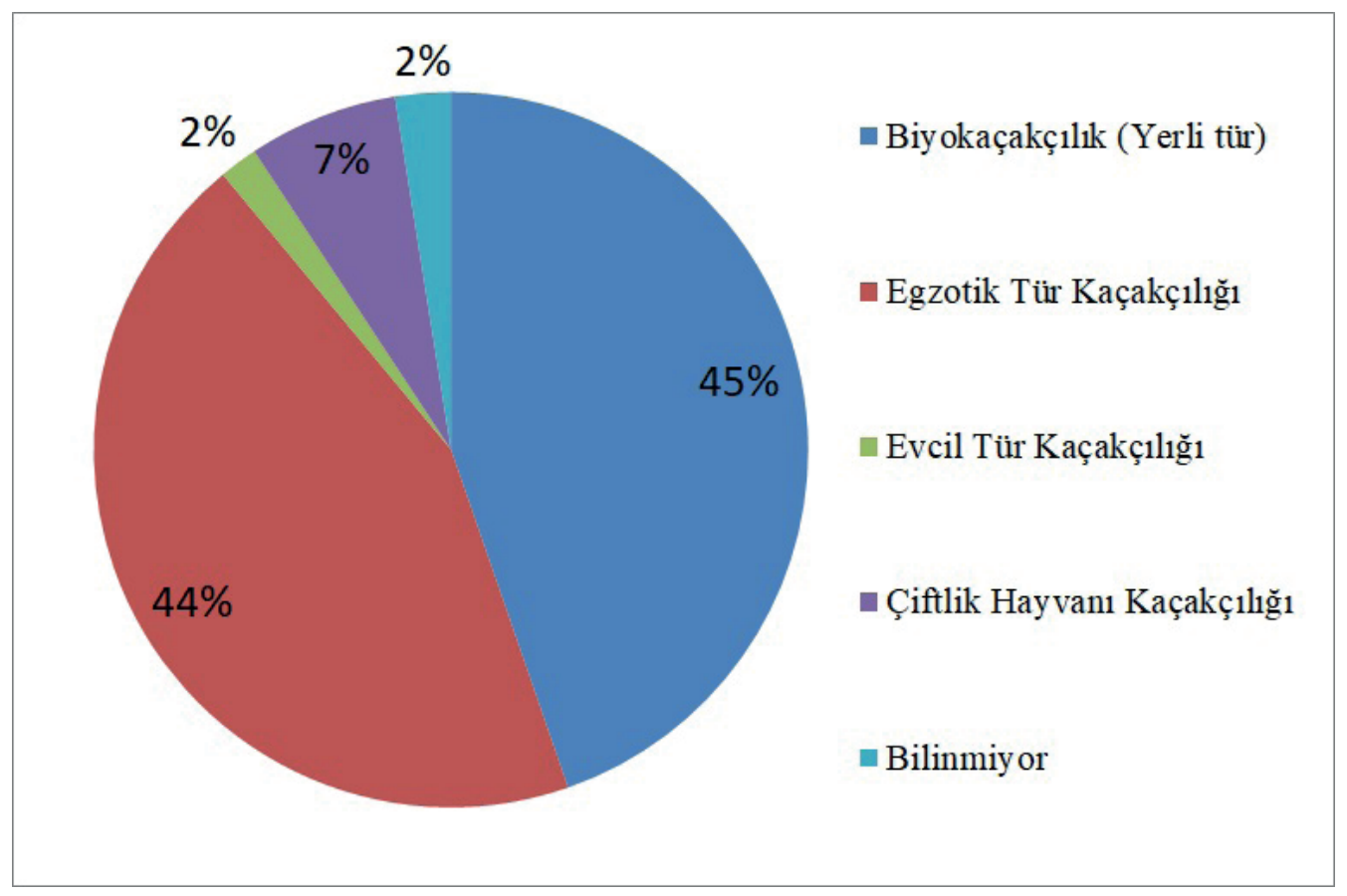

Şekil 9. Farklı statülerden canlı gruplarının maruz kaldığı kaçakçılık oranları 


\section{SONUÇ ve TARTIŞMA}

Biyokaçakçılık; art niyetli kişilerin bir coğrafyanın zengin biyoçeşitliliğinin farkında olmaları sonucu bu zenginlikten maddi kazanç sağlamak için seçmiş oldukları yasa dışı bir yoldur (Dayığlu vd., 2019). Türkiye'de biyokaçakçılık yaban hayatına ait türleri kapsıyor olsa da başka ülkelere özgü egzotik türler ile evcil, büyükbaş ve küçükbaş hayvanların Türkiye'deki karar verici kurumlardan izinsiz bir biçimde taşınması ve ticaretinin yapılması da yasaktır ve bu konuda cezai yaptırımlar mevcuttur. $\mathrm{Bu}$ gibi vakalar kitle iletişim araçlarına haber olarak yansımaktadır. Bu haberler bilimsel araştırmalar için veri alt yapısı sağlayabilmektedir. Bu araştırmada 1999-2020 yılları arasında Türk medyasına yansımış olan bitki, hayvan ve mantar temelli 517 kaçakçılık haberi bir veri tabanı haline getirilerek değerlendirilmiştir. Bu veri tabanına göre; Türkiye'de mantar kaçakçılığ haberleri çok düşük düzeydedir. Kaçakçılıkta hayvanlar ile ilgili haberlerin, bitkiler ile ilgili haberlerin üç katı olmasında egzotik, evcil ve çiftlik hayvanları kaçakçılığının önemli bir etkisi vardır. Ayrıca hayvan kaçakçılığı vakalarındaki egzotik türlerin varlığı gelecekte bu türlerin ekolojik, ekonomik ve sosyal etkileri değerlendirilirken önemli olacaktır. İstilacı yabancı türlerin biyolojik çeşitlilik üzerindeki baskısı nedeniyle egzotik türlerin izlenmesi gereklidir. Özellikle küresel iklim değişikliğinin etkilerinin belirginleşmesinden sonra en büyük küresel sorunun istilacı türler olduğu göz önüne alınırsa, biyokaçakçılık ile mücadelenin istilacı türlerle mücadele ile koordinasyon içinde yürütülmesi zorunludur.

İki kıtayı birbirine bağlayan ve jeopolitik konumu nedeniyle ticari açıdan bir cazibe merkezi olan Anadolu, kaçakçılık için de cazibe merkezi olmuştur. Türkiye Cumhuriyeti'nin ilk dönemlerinde, Gümrük Muhafaza Müdürlüğü aldığı tedbirlere rağmen İskenderun Körfezi'nden İran sınırına kadar olan güney sınırında kaçakçılığı engelleyememiştir (Gözcü \& Çakmak, 2019). Kaçakçılığın artmasında coğrafi etmenler ile sosyo-psikolojik nedenler de etkilidir. Ayrıca Türkiye'nin güney sınırında güvenlik yıllarca basit tel örgü ve sınır karakolları ile sağlanmıştır (Özgen, 2011).

Türkiye'de ilk biyokaçakçılık vakası Osmanlı İmparatorluğu döneminde lale soğanlarının Hollanda'ya kaçırılması ile ortaya çıkmıştır (Şimşek, 2011). Türkiye'de yılan zehri, kelebek, bombus arısı, şahin, atmaca gibi canlıların ya da bu canlılara ait yumurtaların turist görünümlü biyologlar tarafından kaçırıldığı bilinmektedir (Bacak, 2014). Türkiye'de DKMP 2013 yılında biyokaçakçılık üzerine "Biyokaçakçılıkla Mücadele Rehberi” yayınlamış ve 81 ilde halkı bilinçlendirme ve farkındalık oluşturma çalışmalarına başlamıştır (Yorulmaz, 2014). Biyolojik çeşitliliği etkileyen etmenler içerisinde biyolojik kaçakçılığın önemli bir yeri vardır (Çakır Sümer, 2016). Bu sebeple biyokaçakçılıkla ilgili yapılması gereken hukuki düzenlemeler bulunmaktadır (Başaran, 2017). Biyokaçakçılık vakaları resmi kayıtlara geçenlerden çok daha fazladır, hukuki süreç iyi işlememekte ve ilgili kamu personellerinin konu ile ilgili bilgi düzeyi yetersiz kalmaktadır (Güler \& Mutlu 2018). Türkiye'de biyokaçakçılığın durumu birkaç örnekle bakanlık raporları doğrultusunda incelenmiştir (Kurt vd., 2019). Türkiye'de evcil ve egzotik kökenli hayvanların ithalatı yasal olarak 2020 yılının şubat ayına kadar yapılabilmiştir. Ancak 2020 yılının şubat ayında baş gösteren küresel Covid 19 salgını sebebiyle evcil ve egzotik kökenli hayvanların ithalatı Tarım ve Orman Bakanlığı tarafından bir yıl süre ile askıya alınmıştır (Tarım ve Orman Bakanlığı, 2021). Türkiye'de biyokaçakçılık üzerine şimdiye kadar yapılmış olan araştırmalar başlangıç düzeyindedir, Türkiye’nin biyoçeşitliliğinin korunması ve halkın farkındalığının artırılmasına dair her araştırma önemlidir. Özellikle kitle iletişim araçlarının bu konuda önemli bir misyonu vardır. Bu konunun sadece biyokaçakçılık özelinde değil, çiftlik, evcil ve egzotik türleri de kapsayacak biçimde değerlendirilmesi ile daha bütüncül yaklaşımlar geliştirilebilir.

Türkiye'de dijital habercilik 2000 yılından itibaren hız kazanmış ve medya kuruluşlarının internet sitelerini kamuoyuna açmasında bir artış olmuştur (Aydoğan, 2013). CITES sözleşmesine göre yapılan yasal düzenlemeler 2004 yılında resmî gazetede yayınlanmış ve denetimler artırılmaya başlamıştır. Araştırma konusu olan kaçakçılık haberlerinin artışı da bu gelişmelerle paralellik göstermektedir (Şekil 1). Toplumda oluşan farkındalık ile vakaların haber değeri kazanması ve internet temelli haberciliğin yaygınlaşması, yerel haberlerin ülke genelinde erişilebilir hale gelmesi, ulaşılan verilerin artışında bir diğer etken olarak değerlendirilebilir. 2010 yılından itibaren kaçakçılığı yapılan bitki türleri arasında dikkat çekici bir biçimde uyuşturucu-halüsinojen madde içerikli türlerin yer alması günümüzde artan madde bağımlılığı ve buna paralel olarak artan kaçak bitki yetiştiriciliği vakaları ile de doğru orantılı olabilir. Yerel ve ulusal haberlerde bitki, hayvan ve mantar kaçakçılığ vakalarının oransal değişimi farklıdır. Ulusal haberlerin \%82'si, yerel haberlerin \%55'i hayvanlar üzerinedir (Şekil 2). Bu farklılık; yerel düzeyde her vakanın haber değeri taşıması, ulusal düzeyde ise en dikkat çekici olanların haber değeri 
taşımasından kaynaklanıyor olabilir. Genel olarak medyada yanlış ya da hatalı haber yapılma durumu söz konusudur, ancak bu çalışmada kullanılmış haberler genellikle resmi kurumlar tarafından basınla paylaşılmış olan vakalardır. Bulut analizinde en fazla haber kaynağına ulaşılan anahtar kelimelerden birinin kaçakçılık mücadele şube müdürlüğü olması (Şekil 8) da bu durumun bir göstergesidir.

$\mathrm{Bu}$ araştırmada Marmara Bölgesi’ne ait verilerin diğer bölgelerin neredeyse tamamının toplamına yakın bir orana sahip olmasının (Şekil 3) başlıca sebepleri; İstanbul Havalimanı, Edirne ve Kırklareli sınır kapılarında ele geçirilen örneklere dair haberlerdir. Akdeniz Bölgesi ile Doğu Anadolu ve Güneydoğu Anadolu bölgelerinin oranları ise bu bölgelerde yoğun şekilde meydana gelen sahlep soğanı toplayıcılığı ve ilgili bölgelerin endemik türler açısından zengin habitatlar barındırıyor olması ile ilişkilendirilebilir. Ayrıca Doğu Anadolu ve Güneydoğu Anadolu Bölgeleri büyükbaş-küçükbaş hayvan kaçakçılığı ile kaçak kenevir yetiştiriciliğinde de dikkat çeken bölgelerdir. Gümüşhane ili ise, dünyadaki üç biyoçeşitlilik sıcak noktasının kesiştiği yer olan Anadolu Çaprazı üzerinde bulunması ve sahip olduğu zengin biyoçeşitlilik değerleri ile kaçakçılık açısından dikkat çekmektedir

İstanbul, Edirne, Kırklareli ve Tekirdağ'da yapılan haberler (Tablo 2) havalimanı ve sınır kapısında yakalanmalar üzerine olup, haber içerikleri çoğunlukla ihbar temelli olan vakalar üzerinedir. Diyarbakır'daki yüksek oran ise temelde kaçak hint keneviri yetiştiriciliği sebebiyledir. Kütahya ve çevresi haşhaşın izne tabi yasal yetiştiriciliğinin yapıldığı ve aynı zamanda haşhaş tohumunun gıda maddesi olarak tüketiminin yüksek olduğu bir bölgedir. Bu nedenle, haşhaş kaçakçılığı haberlerinin dağılımında Kütahya'nın ön planda olduğu düşünülmüştür. Gümüşhane ili ise dünyadaki üç biyoçeşitlilik sıcak noktasının kesiştiği yer olan Anadolu diyagonali üzerinde bulunmaktadır. Bu nedenle sahip olduğu zengin biyoçeşitlilik değerleri ile kaçakçılık açısından dikkat çekmektedir.

Haber içerikleri, toplumsal bilincin sağlanmasında önemlidir. Haberlerde görsel verinin olması, haberin güvenilirliğini artırmakla birlikte, hitap ettiği kitlede yaratılacak farkındalık açısından dikkat çekici bir öge niteliği taşımaktadır. Tespit edilen haberlerin yarıdan fazlası görsel veri bulundurmasına karşın (Tablo 1), ilgili görsellerin çoğu düşük çözünürlüğe sahip ve tür tanımlama açısından yetersizdir.

Türkiye'de sadece Amanos Dağları'nda yaşayan altı antenli Akbez geyik böceği (Lucanus cervus akbesianus), özellikle Japonya'da, yaygın olan "Böceklerin Kralı” (Mushiking-King of the Beetles) adlı çizgi film, roman ve kart oyunları nedeniyle çocukların ve koleksiyoncuların ilgisini çeken, ekonomik değerinden ötürü kaçakçıların en çok aradığı türlerden biridir (Dayığlu vd., 2019). Türkiye'deki kaçakçılık haberlerine konu olan organizmalar sistematik açıdan incelendiğinde (Tablo 3), bazı vakalarda tür adlarının olmaması bu araştırmanın yer yer takım ve cins temelli bir kıyaslama ile sınırlı kalmasına neden olmuştur. Bu bilgi eksikliğinin farklı nedenleri olabilir. İlgili tür teşhis edilememiş olabilir ya da geyik böceği örneğindeki gibi bir durum olmaması ve ilgili türün doğadaki geleceği için anonim bırakılmış olabilir. Yerli türler ile ilgili yapılmış olan haberlerde hem tür hem de yer bilgisi olması kaçakçılara doğrudan adres gösteriyor olabilir. Hatta ilgili türü tanımayanlar yanlışlıkla alandan farklı canlı türlerini de toplayabilirler. Bu nedenle haber içerikleri hakkında ayrı bir değerlendirme yapılabilir.

Elde edilen veriler doğrultusunda, Squamata (Pullular) takımı; evcil hayvan olarak tercih edilen kertenkele, kaplumbağa gibi canlı gruplarına ilaveten deri ve pul ticareti ile en yüksek orana sahiptir. Carnivora (Etçiller) takımının oranı evcil kedi ve köpekler nedeniyle yüksektir. Carnivora'dan sonra kuşlara ait takımlar olan; Psittaciformes (Papağanlar), Passeriformes (Ötücüler) ve Anseriformes (Kazsılar) gelmektedir. Artiodactyla (Çift toynaklılar) takımındaki yüksek oran (Tablo 3) ise çoğunlukla büyükbaş ve küçükbaş hayvan kaçakçılığından kaynaklanmaktadır. Kaçakçılık haberleri toplam 61 ilde yapılmıştır ve ele geçirilen canlıların çeşitliliği her ilde aynı değildir. Bu farklılık illerin coğrafik, ekolojik, sosyo-ekonomik özelliklerinden kaynaklanıyor olabilir. Dolayısıyla kaçakçılığg engellemek için yapılacak çalışmalarda bunların da göz önünde bulundurulması önemlidir.

Yeşil papağan (Psittacula krameri) insan etkisiyle Türkiye'de doğada üreyen popülasyonlar kurmuş olmasına rağmen ülkede ticareti yapılmaya devam eden bir türdür (Per, 2018). Büyük şehirlerde bu türe ait bireylerin yasa dişı biçimde doğadan toplandığı bilinmektedir (Per, 2019). Bu türün Türkiye’ye ithalatı 2021 yılında Tarım ve Orman Bakanlığı tarafından 
yasaklanmıştır, ancak daha önceki yıllar getirilmiş olan bireyler nedeniyle ülke içindeki ticareti hala devam etmektedir (Per, 2021). Bu araştırmada hayvan kaçakçılığından en çok etkilenen hayvan sınıfı kuşlardır (Şekil 4), kuşlar arasında da papağanlar ön plana çıkmıştır (Tablo 1). Tür temelli olarak da yeşil papağan’ın yasa dışı olarak kaçakçılığı yapılan bir tür olduğu tespit edilmiştir. Türe yönelik ithalat yasağı gelmiş olmasına rağmen, ülke içinde yasa dışı olarak doğadan toplama vakaları ve kaçakçıllğı da devam ettiği için bu türün iç piyasadaki ticaretinin uzun yıllar devam edeceği düşünülmektedir. İthalat yasağının ülke içinde başarıya ulaşması için Tarım ve Orman Bakanlığı'nın bu konuda farklı ilgi grupları ile kamu, STK ve üniversite işbirliğinde yeni yaklaşımlar geliştirmesi faydalı olacaktır.

Eğer bir tür ticareti yapılamayacak kadar nadir hale gelirse, bir yasak gelinceye kadar yasal satışları artar, yasak gelince de yasa dışı satış fiyatları yükselir (Coulon \& Nouet, 2018). Nesli tehlike altında olan Gri papağan (Psittacula erithacus) Türkiye'de 1982-2016 yılları arasında yasal olarak en çok ticareti yapılan papağan türü olmuştur. Gri papağan'ın doğal popülasyonları çok azaldığı için 2017 yılında dünya genelinde ticareti yasaklanmıştır (Per, 2018), ancak Türkiye'deki yaban hayatı kaçakçılığı vakalarında bu türe ait bireylere rastlanılmıştır.

Afrika Boğa Kurbağası (Pyxicephalus adspersus) ve kızıl palmiye böceği (Rhynchophorus ferrugineus) dünyadaki istilacı yabancı türler arasında yer almaktadır (GISD, 2021). CITES'e göre Türkiye yasal olarak bu türlerin ticaretini yapmamaktadır (CITES, 2021). Ancak bu araştırmada Türkiye'deki kaçakçılık vakalarında bu türler tespit edilmiştir. İstilacılık özelliği olan egzotik türler ile ilgili karar verici kurumların toplumu bilinçlendirmesi ve geleceğe dönük önlemler alması gereklidir.

Türkiye'de ilk kez 2005 yılında Mersin'de tespit edilen kızıl palmiye böceği (Rhynchophorus ferrugineus) peyzaj amaçlı dikilmekte olan palmiye ve hurma ağaçları aracıllğıyla ülkeye girdirilmiştir (Karut \& Kazak, 2005). Kaçakçıllğa konu olan haber ise 2011 yılında Antalya'da yaşanmıştır. Yabancı bir akademisyen doğadan topladığı kızıl palmiye böceklerini ülkesine göndermek isterken kargo şirketinin dikkati ve ihbarı ile tespit edilmiştir (AA, 2011). İT ile mücadelede başarılı olmak için toplumun bütün kesimlerini kapsayacak şekilde bir farkındalık çalışması ve veri tabanı alt yapısına ihtiyaç vardır (Uludağ \& Ertürk, 2012).

Haberlere konu olan bitkiler sistematik açıdan incelendiğinde ise, hayvanlarda olduğu gibi bazı tür adlarına ilişkin yeterli düzeyde yazılı ve görsel verinin sağlanamaması bu incelemenin takım ve cins düzeyinde sınırlı kalmasına neden olmuştur (Tablo 4). Endemik tür kaçakçılı̆̆ında; bitki soğanları ve tohumları ön plandadır. Elde edilen veriler doğrultusunda, Rosales (güller) \%46.8 ve Ranunculales (düğünçiçekleri)'in \%26,6 ile en yüksek orana sahip olmasının sebebi, ilgili bitkilerin Türkiye'de; kaçak olarak ekimi yapılan hint keneviri ve haşhaş yetiştiriciliği olabilir. Bu araştırmada tespit edilen bitki kaçakçılığı vakalarının yarısından çoğu (hint keneviri \%45 ve haşhaş \%25), uyuşturucu-halojen etki yaratan türlere yönelik kaçakçılık vakalarıdır. Bu sıralamada üçüncü sıradaki Asparagales (kuşkonmazlar) takımının yüksek \%'lik dilimi sahlep soğanı kaçakçılığına ilişkin haberler nedeniyledir (Tablo 4). Cins bilgisine ulaşılan vakalar içerisinde, Cannabis (kenevir) ilk sırayı alırken bunu Papaver (haşhaş) ve Ophrys (sahlep) takip etmektedir (Şekil 5). Mantarlarda ise Pezizales takımı yer almaktadir.

Türkiye'deki yabani bitki soğanlarının yabancı araştırmacılar ve bahçe sahipleri tarafından izinsiz olarak toplanıp farklı ülkelere taşındığı bilinmektedir. Özellikle dar yayılışlı, nadir ve endemik türler bu durumdan olumsuz etkilenmektedir. Ophrys türlerinin 1974 yılından beri ihracatı yasaktır (Ekim \& Koyuncu, 1993). Macar araştırmacılar tarafından 2015 yılında yurt dışına kaçırılmak istenirken el konulan Likya Kaş orkidesi'ne ait yumrular doğaya kazandırılmak amacıyla Likya Kaş Orkidesi Özel Koruma Alanı’na yeniden dikilmiştir (Ulusal, 2015). Ophrys türlerinin bu araştırmadaki bitki cinsleri arasındaki vaka oranı \%1'dir (Şekil 5). Tür seviyesinde sadece Likya Kaş orkidesi'ne ait vaka tespit edilmiştir.

Son yıllarda organizmanın bir bütün olarak kaçırılması yerine herhangi bir doku örneğinin kaçırılması moleküler çalışmaları gerçekleştirmek için yeterli olmaktadır. Taşımaya uygun tüp vb. kaplarda uygun çözeltiler (örneğin, formaldehit, alkol) içinde korunarak taşınabilen bu doku, parça ve sıvılar kolaylıkla yurt dışına çıkarılabilmektedir (Yorulmaz, 2014). Boynuz, diş, deri, post, tırnak, tüy, kıl, yumurta, dışkı, zehir, tohum, yumru gibi örnekler de benzer yöntemlerle kaçırılabilmektedir (Akın, 2019). Biyolojik ve ekolojik araştırma yöntemleri ile teknolojideki gelişim ile birlikte Türkiye'de biyokaçakçılık bir değişim göstermiş̧ir. Son on yılda kaçırılması daha zor olan bitki ve hayvan bireyleri yerine spesifik olarak belirli organizma parçaları özellikle de bitki soğanı, hayvan postu, kabuğu ve diş örneklerinin kaçakçılı̆̆ında dikkat çekici bir artış olmuştur 
(Şekil 7). Bu araştırma ile özellikle Covid 19 pandemisi ile gündeme gelmiş olan Pangolin (Pholidota) pulunun yanı sıra fil ve mors dişlerinin de Türkiye'de kaçakçılığının yapıldığı tespit edilmiştir.

Kaçakçılık vakaları arasında çiftlik hayvanı kaçakçılığı \%7 ile düşük bir orana sahiptir (Şekil 9). Bu durumun ortaya çıkmasında Tarım ve Orman Bakanlığı’nın yürütmekte olduğu hayvan kayıt, kimliklendirme ve küpeleme çalışmalarının etkili olduğu düşünülmektedir.

Kaçakçılık vakaları arasında evcil hayvan kaçakçılığı \%2'lik bir orana sahiptir (Şekil 9). Tarım ve Orman Bakanlığı tarafından evcil kedi \& köpeklerin kayıt altına alınması ve kimliklendirilmesi için 01.01.2021 tarihinden itibaren evcil hayvanlara mikroçip takılması zorunlu hale getirilmiştir (Resmî Gazete, 2018). Böyle bir kararın alınmasının bu hayvanların başıboş hayvan statüsünde doğada var olma durumunun azaltılmasında yararlı olacağı düşünülebilir, ancak bu kararın evcil hayvan kaçakçılığı üzerindeki etkileri gelecek yıllarda tespit edilebilecektir.

Yaban hayatı kaçakçılığı Türkiye’ye sosyo-ekonomik olarak zarar vermektedir; yasa dışı yollar ile getirilen canlıların orjini (doğadan toplanan veya kafeste yetiştirilen bireyler), yetiştirildiği ülke, yetiştirilme yöntemi (gruplar halinde veya çift olarak) beslenme rejimi, bağırsak florası, ve taşıdı̆̆ı genetik mutasyonları bilinmemektedir. Bu bireyler karantinaya alınmadan ticaret döngüsüne girdirildiği için biyogüvenlik, hayvan refahı ve halk sağlığı açısından risk oluşturmaktadır. Aynı zamanda yasal olarak ticaret yapan firmalar da bu durumdan olumsuz etkilenmektedir; ülkeye kontrolsüz olarak birey sayısı ve tür çeşitliliği belirsiz canlılar girdirildiğinde ülke içindeki piyasa değerleri değişebilmektedir. İç piyasaya yayılması durumunda kontrolü yapılamadığg için haksız rekabet ortaya ortaya çıkabilmektedir.

Japonya 1979-2015 yılları arasında 92 ülkeden 603 kuş türü ithal etmiştir, en çok ithalat yaptığı ülkeler; Belçika, Hollanda ve Singapur'dur (Vall-Llosera \& Su, 2018). Türkiye 1982-2016 yılları arasında 60 ülkeden 135 papağan türü ithal etmiştir. Ticari amaçla ithal edilen bu papağanların \%64'ü insan elinde kafes kuşu olarak yetiştirilmiştir ve bu dönemde en çok ithalat yapılan ülkeler; Çek Cumhuriyeti, Hollanda, Guyana, İsviçre, Belçika ve Mali'dir (Per, 2018). Dünya'da farklı ülkeler arasında kafeslerde yetiştirilmiş kuşların ithalatı ve ihracatı yapılmaya devam edilmektedir. Türkiye'de yaban hayatı kaçakçılığından en fazla etkilenen hayvan sınıfı kuşlar olup bu durum uluslararası ticaret yapmaya çalışan yerli firmaları da olumsuz etkilemektedir.

Türkiye'de kamusal alanda biyokaçakçılıkla mücadele için oluşturulmuş bir yönetim birimi, teşkilat veya bir organizasyona rastlanılmamıştır. Biyokaçakçılığı önleme konusunda kamuda yeterli personel bulunmamaktadır. Türkiye'den yurtdışına yerel tür kaçakçılığı yapan yabancı uyruklu kişiler olabildiği için bu konuda sıkı tedbirlere ihtiyaç vardır (Güler \& Mutlu, 2018). Bunun yanı sıra doğa turizmi adı altında biyoçeşitlilik hakkında nitelikli kişilerin yurt dışından gelerek yaptığı geziler de sıkı takip altında tutulmalıdır. Son yıllarda alternatif turizm seçeneklerinden biri olan doğa turizmini artırmaya yönelik çalışmalar hız kazanmaktadır. Nitelikli biyokaçakçılığa zemin hazırlayacak ortamların oluşmasını engellemek amacıyla, ilgili aktiviteleri düzenleyenler ile ziyaretçilere rehberlik edecek kişilerin biyokaçakçılık üzerine eğitilmesi büyük önem arz etmektedir. Yine bu kapsamda, biyokaçakçılık ile mücadele birimlerinin devlet otoriteleri tarafından kurulması ve bu yönde çalışmalar yapacak personelin bitki ve hayvan taksonomisi ile ekoloji üzerine yeterli bilgi ve donanıma sahip kişiler arasından seçilmesi yahut bu konuda eğitilmesi elzemdir.

19. Yüzyıldan beri devam eden yaban hayatı tahribatı, aşırı tüketim, kirlilik, epizootik ve epidemik hastalıkların ortaya çıkışı insanın doğaya saygı göstermemesi ile daha da artmıştır. Dünya'da 1.000'e yakın canlı türünün yok olduğu bilinmektedir, yakın gelecekte 17.000 türün de neslinin tükeneceği tahmin edilmektedir. Hayvan hakları kavramının kabul edilmesi uzun yıllar almıştır, ancak hayvan hakları ve çevre sorunları üzerine çalışmakta olan uluslararası kurumlar sayesinde günümüzde hayvana saygı kavramında önemli bir ilerleme kaydedilmiştir (Coulon \& Nouet, 2018). Hayvan ticareti konusunda Avrupa'da çok fazla yönerge ve tavsiye çıkarılmış olmasına rağmen hâlâ hayvanlar uygun olmayan koşullarda uzun mesafelere taşınmaktadır. Ayrıca CITES hakkında eğitilmiş ve koruma altındaki türleri tanıyabilen personel sayısı azdır (Coulon \& Nouet, 2018). Türkiye'de de yerelde çalışanların tür tanımaya yönelik bilgi düzeyi bilinmemektedir. Bu konuda yapılmış olan haberlerde kaçakçıların sadece gümrüklerde değil, arazide canlıları toplarken ve yol üzerinde yapılan denetlemelerde canlıları taşıma sırasında da yakalandı̆̆ı tespit edilmiştir.

Sürdürülebilir kalkınmada uzun vadeli kalkınma hedeflerinin doğa koruma ve çevresel değerler gözetilerek planlanması gereklidir. Doğa koruma için halkın bu konudaki fikirleri benimsemesi ve sürece dahil olması gereklidir (Kışlalığlu ve Berkes, 2019). Bilim toplumdan ayrı bir faaliyet değildir, hatta her şeyden çok toplumsaldır (Saygın Öğütle vd., 2019). Yaban 
hayatını korumak ve hızlı hareket etmek için iletişim ve bilgilendirme gereklidir, bu bağlamda medya önemli bir araçtır (Blewitt, 2011). Televizyonda evcil hayvanlar ve yabani hayvanlar üzerine hazırlanmış programlar daha çok ilgi çekerken hayvan ticareti ve esaret altındaki canılara dair programlar daha az ilgi görmektedir. Bu açıdan günümüzde internet halkın farkındalı̆̆ının artırılmasında önemli bir yere sahiptir (Coulon \& Nouet, 2018). Türkiye'de karar verici kurumların hem kurumsal internet sayfalarında hem de medya kuruluşları ile paylaştıkları haberlerde bu konuya yer vermeleri toplumda biyokaçakçılık ile ilgili farkındalık oluşmasına önem verdiklerini göstermektedir. Karar verici kurumlarda yeterli sayıda biyolog bulunmayışı biyokaçakçılığın etkisini kolluk kuvvetleri ve halka ifade ederken sınırlayıcı olabilir. Bu konuda özellikle yerel halkın ihbarları kaçakçıların yakalanması açısından büyük önem arz etmektedir. Ayrıca bilimsel çalışmalardan elde edilen bulguların halka anlaşı1ır biçimde sunulması gereklidir.

Türkiye'de 2013 yılından itibaren biyokaçakçılık konusunda karar verici kurum olan Tarım ve Orman Bakanlığı'nın yaptığı farkındalık çalışmaları ile biyokaçakçılık sorunu dikkat çekmeye başlamıştır, ancak bu çalışmalar, vatandaşlara Türkiye'de biyokaçakçılığın boyutları hakkında yeterli veri sunmamaktadır. Toplumun biyokaçakçılık konusunda bilinç düzeyini artırmada en etkili kaynaklar; kitle iletişim araçlarıdır. Bu araştırma ile ülke genelinde ilk kez medyada biyokaçakçıllk ve yaban hayatı kaçakçılı̆̆ı ile ilgili bir değerlendirme yapılmıştır. Değerlendirmede vakalar kaçakçılığın yapıldığı coğrafi bölge, il, kaçakçılığa maruz kalan canlı grubu ve bu organizmalara ait parçalar, haberin yapıldığı tarih, haberin ölçeği ve görselleştirme teknikleri gibi çeşitli kategoriler açısından sınıflandırılmıştır. Haber içeriklerinde görsel verinin bulunması haberin güvenilirliğini artırmakla birlikte, hitap ettiği kitlede yaratılacak farkındalık açısından önemlidir. Türkiye'de 21 yıllık süreçte kaçakçılık vakaları üzerine yapılmış olan 517 haberin dörtte biri bitkiler üzerinedir. Kaçakçılığın en çok yapıldığı coğrafi bölge hava ve karayolu kaçakçıllğının yoğun olarak görüldüğü Marmara Bölgesi’dir. Covid 19 kısıtlamaları ile birlikte 2020 yılında Türkiye'de yaban hayatı kaçakçılık vakaları artmıştır. Bir yıl süre ile uluslararası yaban hayatı ticaretinin askıya alınmış olmasının bu durumun ortaya çıkmasında etkili olduğu düşünülmektedir. Ayrıca bu durum pandeminin halk üzerinde yarattığı ekonomik krizin bir etkisi sonucu da olabilir. Halkın biyokaçakçılık konusundaki bilinç düzeyi bilinmemektedir. Gelecekte bu alanda vatandaş bilimi ve sosyal medya temelli araştırmalara ihtiyaç vardır.

Hakem Değerlendirmesi: Dış bağımsız.

Çıkar Çatışması: Yazarlar çıkar çatışması etmemişlerdir.

Finansal Destek: Yazarlar finansal destek beyan etmemișlerdir.

Yazar Katkıları: Çalışma Konsepti/Tasarım- E.P.; Veri Toplama- K.G.A., Ö.G.B.,B.Y.,E.P.; Veri Analizi/Yorumlama- K.G.A., Ö.G.B.,B.Y.,E.P.; Yazı Taslağı- K.G.A., Ö.G.B.,B.Y.,E.P.; İçeriğin Eleştirel İncelemesi- K.G.A., Ö.G.B.,B.Y.,E.P.; Son Onay ve Sorumluluk- K.G.A., Ö.G.B.,B.Y.,E.P.

Teşekkür: Türkiye'de biyokaçakçılık ve yasal mevzuat hakkında verdikleri bilgiler için Fatma Danışman ve Sühendan Karauz'a, yasal olarak yapılmakta olan hayvan ticareti konusunda verdikleri bilgiler için Ceyhun Güler ve Orhan Dağcı'ya ve önerileri ile makaleye değerli katkılar sağlamış olan Zafer Karaer, Ayşe Yazlık ve Gökçe Coşkun'a teşekkür ederiz.

Peer-review: Externally peer-reviewed.

Conflict of Interest: The authors have no conflict of interest to declare.

Grant Support: Authors declared no conflict of interest.

Author Contributions: Conception/Design of Study- E.P.; Data Acquisition- K.G.A., Ö.G.B.,B.Y.,E.P.; Data Analysis/Interpretation- K.G.A., Ö.G.B.,B.Y.,E.P.; Drafting Manuscript- K.G.A., Ö.G.B.,B.Y.,E.P.; Critical Revision of Manuscript- K.G.A., Ö.G.B.,B.Y.,E.P.; Final Approval and Accountability- K.G.A., Ö.G.B.,B.Y.,E.P.

Acknowledgement: We would like to thank Fatma Danışman and Sühendan Karauz for providing information on biosmuggling and legal legislation in Turkey, Ceyhun Güler and Orhan Dağcı for informing us about legal animal trade, and Zafer Karaer, Ayşe Yazlık, Gökçe Coskun for their valuable contributions to the article with their suggestions.

\section{Kaynaklar/References}

AA. (2011). Anadolu Ajansı, Antalya'da tatil yaptığı otelin çevresinde yakaladığı böcekleri Almanya'ya göndermek isteyen profesör gözaltına alındı, 27.08.2011, Antalya, , Türkiye.

Akman, Y., Düzenli, A., \& Güney, K. (2005). Biyocoğrafya. Palme Yayıncılık. Ankara, Türkiye.

Akın, H. Y. (2019). Fen Bilimleri Öğretmen Adaylarının Biyolojik Kaçakçılık Kavramına Yönelik Görüşleri, Burdur Mehmet Akif Ersoy Üniversitesi, Eğitim Bilimleri Enstitüsü, (Yüksek Lisans Tezi). Retrieved from https://tez.yok.gov.tr/UlusalTezMerkezi.

Aruoba, Ç. (2005). Biyolojik Çesitlilik Sözlesmesi’nin 11. Maddesi: Ekonomik Tesvikler. Biyogüvenlik Protokolü ve Biyolojik Çesitlilik Sözlesmesi’nde Tesvikler, Tartısma Toplantısı 17-18 Subat 2005, Mayıs 2005, Türkiye Çevre Vakfı Yayını, ss. 31-40.

Aydoğan, D. (2013). Türkiye'de dijital gazetecilik: Habertürk ve Hürriyet gazeteleri örneği. The Turkish Online Journal of Design Art and Communication, $3(3), 26-40$.

Bacak, E. (2014). Türkiye’nin Fauna Zenginliği, İ.Ü. OMYO Avcı1ık ve Yaban Hayatı Programı. İstanbul Üniversitesi Kongre Merkezi, İstanbul, 26 
Haziran 2014.

Başaran, G. (2017). Türkiye’de Biyokaçakçılık, Dumlupınar Üniversitesi Fen Bilimleri Enstitüsü (Yüksek Lisans Tezi). Retrieved from https://tez.yok. gov.tr/UlusalTezMerkezi.

Bergman, C. (2009). Stolen Wildlife: The Illicit Animal Trade Is Exceeded Only by Drugs and Weapons Trafficking. Smithsonian, 40: 34-42.

Blewitt, J. (2011). The media, animal conservation and environmental education, Environmental Education Research, 17(6), 711-718

Budak, A., \& Göçmen, B. (2008). Herpetoloji. Ege Üniversitesi Yayınları Fen Fakültesi, Yayın No. 194.

Carson, R. (1962). Silent Spring. Houghton Mifflin, Boston.

CITES Secretariat. (2021). CITES (The Convention on International Trade in Endangered Species of Wild Fauna and Flora), Retrieved from https://www. cites.org.

Coulon, J. M., \& Nouet, J. C. (2018). Hayvan Haklarl, Kırmızı Kedi Yayınevi, İstanbul.

Çakmak, M. (2008). Biyolojik Çesitliliğin Hukuken Korunması ve Kamu Yararı. Ankara Üniversitesi Hukuk Fakültesi Dergisi, 57(1), 133-166.

Dayığlu, H., Yılmaz, A., \& Başaran, G. (2019). Türkiye’de Biyokaçakçılık, Dumlupınar Üniversitesi Fen Bilimleri Enstitüsü Dergisi, 43: 74-90.

Ekim, T., \& Koyuncu, M. (1993). Türkiye’den İhraç Edilen Çiçek Soğanları ve Koruma Önlemleri, 2. Uluslararası Ekoloji ve Çevre Sorunları Sempozyumu (Ed. Kiziroğlu, İ), Türk-Alman Kültür İşleri Kurulu Yayın Dizisi No:3, Ankara, 42-47.

GISD. (2021). Global Invasive Species Database. Retrieved from http://www.iucngisd.org/gisd.

Gözcü, A., \& Çakmak, F. (2019). Cumhuriyet'in ilk yıllarında Türkiye’nin güney sınırında gerçekleştirilen kaçakçılık faaliyetleri. Dokuz Eylül Üniversitesi Sosyal Bilimler Enstitüsü Dergisi, 21(3), 683-714.

Güçlü, B., \& Kökmen, M. B. (2014). Sosyal Medya Perspektifinde Gazete Okuma Alışkanlığı, Retrieved from https://www.academia.edu.

Güler, E., \& Mutlu, A. (2018). Türkiye’de Biyokaçakçılık Sorunu: Küre Dağları Milli Parkı Örneği. 12.Uluslararası Kamu Yönetimi Sempozyumu Bildiriler e-kitab1, 978-605-84963-1-6, 500.

Güner, A., Aslan, S., Ekim, T., Vural, M., \& Babaç, M.T. (2012). Türkiye Bitkileri Listesi (Damarlı Bitkiler), İstanbul: Nezahat Gökyiğit Botanik Bahçesi ve Flora Araştırmaları Derneği, 1-1290.

Gürcüoğlu, S. (2013). Türkiye'de Çevre Eğitiminde Kamu Örgütleri, Sivil Toplum Örgütleri ve Medyanın Rolü. Gazi Üniversitesi İkstisadi ve İdari Bilimler Fakültesi Dergisi, 15(3), 154-170.

Karut, K., \& Kazak, C. (2005). Akdeniz Bölgesi’nde yeni bir hurma ağacı (Phoenyx dactylifera L.) zararlısı: Rynchophorus ferrugineus (Olivier, 1790) (Coleoptera: Curculionidae). Turkish Journal of Entomology, 29(4), 295-300.

Karagöz, A., Zencirci, N., Tan, A., Taşkın, T., Köksel, H., Sürek, M., Toker, C., \& Özbek, K. (2010). Bitki Genetik Kaynaklarının Korunması ve Kullanımı. Türkiye Ziraat Mühendisliği VII. Teknik Kongresi. Bildiriler (I): 11-15 Ocak, Ankara, s. 155-177.

Keçeli, T., Yaprak, E., Allı, H., Danışman, T., Yorulmaz, T., Kılınçarslan, H., Demircan, A., Kocuklu, B., \& Erdoğan, S. (2013). Biyokaçakçılıkla Mücadele Rehberi, T.C. Orman ve Su İşleri Bakanlı̆̆ı Yayınları, Ankara.

Kence, A. (1991). Biyolojik Çesitlilik ve Kalkınma, Sürdürülebilir Kalkınma El Kitabı, Türkiye Çevre Sorunları Vakfı Yayını, ss. 57-66.

Kışlalığlu, M., \& Berkes, F. 2019. Çevre ve Ekoloji, Remzi Kitabevi, 17. Baskı, İstanbul.

Koç, Y., \& Soykan A. (2020). Dünya'da ve Türkiye'de Doğa Korumanın Kuramsal Temelleri. IBAD Sosyal Bilimler Dergisi, 7: 86-99.

Kurt, O., Çelik, N., Göre, M., \& Kurt, H. (2019). Threats to Biodiversity Bio-Trafficking in Turkey. Turkish Journal of Agriculture-Food Science and Technology, 7: 2, 46-51.Mayr, E., \& İzbırak, A. (2008). Biyoloji budur: canlı dünyanın bilimi. TÜBİTAK Popüler Bilim Kitapları.

Özbek, K. 2016. Biyokaçakcılık. Türkiye Tohumcular Birliği Dergisi, 5(18), 62-68.

Özdemir, G., \& Ceylan, B. (2007). Biyolojik İstila ve Karadeniz'deki İstilacı Türler. Su Ürünleri Merkez Araştırma Enstitüsü, Yunus Araştırma Bülteni. Özgen, H. N. (2011). Sınırda Kaçakçı Olmanın Antropolojik Tarihi. NTV Tarih, Aralık 2011, 24-27.

Öztekin, H., \& Şahin, M. (2020). Medyanın Bilimle İmtihanı: Türkiye’de Gazetelerde Yer Alan Bilim Haberleri Üzerine Bir İnceleme. Akdeniz Üniversitesi İletişim Fakültesi Dergisi, 33: 178-197.

Per, E. (2018). Tropikal ormanlardan Türkiye’ye papağan ticaretinin durumu. Turkish Journal of Forestry, 19(3), $275-283$.

Per, E. (2019). İnternet temelli araçların egzotik papağanların izlenmesine katkısı. Turkish Journal of Forestry, 20 (4), $466-473$.

Per, E. (2021). Understanding the Possible Impact of Exotic Parrots on Human Health. Journal of Anatolian Environmental and Animal Sciences, 6(3), 288-293.

Reece, J. B., Urry, L. A., Cain, M. L., Wasserman, S. A., Minorsky, P. V., \& Orr, R. B. (2020). Campbell Biology, twelfth Edition (Pearson).

Resmî Gazete. (2018). Kedi, Köpek ve Gelinciklerin Kimliklendirilmesi ve Kayıt Altına Alınmasına Dair Yönetmelik, Resmî Gazete Sayısı: 30344, Resmî Gazete Tarihi: 28.02.2018.

Resmî Gazete. (2005). Av ve Yaban Hayvanları ile Bunlardan Elde Edilen Ürünlerin Bulundurulması, Üretimi ve Ticareti Hakkında Yönetmelik, Resmî Gazete, Gazete Sayısı: 25847, Resmî Gazete Tarihi: 16.06.2005.

Resmî Gazete. (2001). Nesli Tehlike Altında Olan Yabani Hayvan ve Bitki Türlerinin Uluslararası Ticaretine İlişkin Sözleşmenin Uygulanmasına Dair Yönetmelik, Resmî Gazete, Gazete Sayısı: 24623, Resmî Gazete Tarihi: 27.12.2001.

Saygın Öğütle, V., Açık-Turğuter, E., \& Banguoğlu, T. 2019. Biyoloji Biliminden Toplumsal Dünyaya Bakmak: Bir Bilim Sosyolojisi Çalışması, DoğuBatı Yayınları, Ankara.Sümer Çakır, G. (2016). Çevresel ve Milli Güvenlik Boyutları Açısından Biyolojik Çeşitlilik ve Tehlikeler. Eskişehir Osmangazi Üniversitesi İIBF Dergisi, 11(1), 207-30.

Şimşek, Ö. (2011). Doğa Casusluğu ve Türkiye'nin Genetik Zenginliği, Nature and liverworts, Retrieved from http://natureandliverworts.blogspot. com/2011/12/doga-casuslugu-ve-turkiyenin-genetik.html

Tarım ve Orman Bakanlığı. (2021). COVID-19 Tedbirleri, Retrieved from https://www.tarimorman.gov.tr/, Erişim: 25.01.(2021). 
Tarım ve Orman Bakanlığı. (2020). Yabani Hayvan ve Bitki Türlerinin Uluslararası Ticaret Konvansiyonu (CITES), CITES Türkiye, Tarım ve Orman Bakanlığı, Retrieved from https://www.tarimorman.gov.tr

Tarım ve Orman Bakanlığı. (2019). Biyolojik Çeşitlilik (2019) yılı Envanter Raporu. Doğa Koruma ve Milli Parklar Genel Müdürlüğü, Ankara.

Tarım ve Orman Bakanlığı. (2007). Ulusal Biyolojik Çeşitlilik Stratejisi ve Eylem Planı (UBSEP). Tarım ve Orman Bakanlığı Doğa Koruma ve Milli Parklar Genel Müdürlüğü Doğa Koruma Dairesi Başkanlığg, s. 22.

Tempier, L. (2014). Building worldwide expertise to detect and seize illegally traded wildlife. In UN chronicle. Ilegal wildlife trade,51: 25-28.

Trakuş. (2020). Türkiye'nin anonim kuşları. Retrieved from http:// www.trakus.org.

Tramem. (2020). Türkiye'nin anonim memelileri. Retrieved from http:// www.tramem.org.

Uludağ, A., \& Ertürk, Y. E. (2012). İthâl Ev Hayvanları ve Süs Bitkilerinin Çevreye Etkileri. Environment. Journal of History Culture and Art Research, 1(4), 428-444.

Ulusal. (2015). Macar Profesörün çaldığg1 orkideler geri dikildi! https://www.ulusal.com.tr/yurt/macar-profesorun-caldigi-orkideler-geri-dikildi-h56326. html.

Vall-Llosera, M., \& Su, S. (2019). Trends and characteristics of imports of live CITES-listed bird species into Japan. Ibis,161 (3), $590-604$.

Wordart, Kelime Bulutu Analizi, Retrieved from http https://wordart.com.

Yıldız, K., \& Sipahioğlu S. \& Yılmaz M. (2005). Çevre Bilimi, Genisletilmis 2. Bask1, Ankara, 1-295.

Yorulmaz, T. (2014). Biyolojik Kaçakçılık ve Omurgalı Hayvanlarımız. Tabiat ve Insan, 187: 3-12. 
